\title{
A new look at oil price pass-through into inflation: evidence from disaggregated European data
}

\author{
César Castro ${ }^{1}$ - Rebeca Jiménez-Rodríguez ${ }^{2}$. \\ Pilar Poncela P $^{3,4} \cdot$ Eva Senra $^{5}$
}

Received: 1 March 2016/Accepted: 10 October 2016/Published online: 21 December 2016

(C) The Author(s) 2016. This article is published with open access at Springerlink.com

\begin{abstract}
This paper analyzes oil price pass-through into inflation at disaggregate level for the euro area and its four main economies (France, Germany, Italy and Spain). The pattern of responses to oil price changes is quantitatively diverse across economies and across items of disaggregate inflation. Moreover, we suggest an alternative method to the direct calculation of aggregate effects on inflation given that indirect and second-round effects may offset the positive effects found in energy inflation and dissipate the effect on total inflation.
\end{abstract}

\begin{abstract}
Financial support from the Spanish Ministry of Economy and Competitiveness, Project Numbers ECO2012-38860-C02-01, ECO2015-70331-C2-1-R, ECO2015-66593-P and ECO2014-56676C2-2-P is acknowledged. Rebeca Jiménez-Rodríguez acknowledges support from the Research Grant SA072U16 (Junta de Castilla y León). The contents of this publication do not necessarily reflect the position or opinion of the European Commission. The work was initiated while the third author was still at Universidad Autónoma de Madrid, Spain.
\end{abstract}

Pilar Poncela

pilar.poncela@jrc.ec.europa.eu

César Castro

ccastrorozo@gmail.com

Rebeca Jiménez-Rodríguez

rebeca.jimenez@usal.es

Eva Senra

eva.senra@uah.es

1 Department of Economics, University of Salamanca, Salamanca, Spain

2 Department of Economics, IME, University of Salamanca, Salamanca, Spain

3 Joint Research Centre (JRC), European Commission, Ispra, Italy

4 Universidad Autónoma de Madrid, Madrid, Spain

5 Department of Economics, Universidad de Alcalá, Madrid, Spain 
Keywords Inflation - Oil prices · Transfer functions · Disaggregation

JEL Classification E31 $\cdot$ C22 $\cdot$ Q43

\section{Introduction}

There are several studies that analyze how non anticipated fluctuations in international crude oil prices affect the developed economies, especially the U.S. (see, e.g., Barsky and Kilian 2004; Kilian 2008; Hamilton 2009a). The origins of crude oil shocks and their mechanisms of transmission into the economy are crucial to understand the effects of crude oil price shocks on variables such as inflation. The recent literature has pointed out the relative importance of global crude oil supply and demand as determinants of rising and falling of crude oil prices (see Kilian 2009). The current exogenous political turmoil (especially in oil producing countries) and the likely oil supply disruptions seem to cause lower significant effects on either inflation or economic growth than they used to. Thus, several authors have studied the possible explanations of the decline in the impact of crude oil price shocks on macroeconomic variables over time (see, e.g., DeGregorio et al. 2007; Chen 2009; Blanchard and Galí 2010; Segal 2011; Valcarcel and Wohar 2013).

In relation with the mechanisms of transmission from crude oil prices into inflation, we can distinguish between direct first-round effects on consumers (higher energy bills, especially in fuels and heating oil), indirect effects on producers (higher production costs on goods and services that use petroleum products as input), and second-round effects related with consumer and producer expectations that cause negative effects on investment and consumption plans (see, e.g., ECB 2010). The recent empirical literature has found that the most important transmission channel of crude oil price shocks to the economy is through a disruption in consumer expenditures due to lower levels of current and expected income (see, e.g., Edelstein and Kilian 2007; Kilian 2008). However, there is no consensus in the literature regarding the nature of the positive/negative effects of an increase in oil price on inflation. On the one hand, inflation movements are related to the falling in the consumer demand for goods and services due to an increase in oil price. These demand side changes may occur through four transmission channels: (a) changes in the discretionary income (i.e., the available money to spend after paying energy bills); (b) uncertainty about future energy prices; (c) precautionary savings; and (d) operating costs effects (see, e.g., Edelstein and Kilian 2009; Kilian 2008). On the other hand, there are indirect effects of crude oil price changes due to an increase in the production costs of goods and services that use energy in their own production processes, although this issue has not been still solved in the empirical literature (see Kilian 2008). Moreover, Hamilton (2009b) points out that magnitude and timing of disruption in consumer's and firm's spending on goods and services, other than energy costs, determine the supply reaction and thus is a main way toward explaining how energy price shocks affect the economy. 
Most of the empirical literature about the effects of changes in crude oil prices on inflation use aggregate measures of inflation or a very simple disaggregation (energy/non-energy), and conclude that there is mainly a direct effect through the energy component, while indirect and second-round effects are commonly less important (see, e.g., ECB 2010; Álvarez et al. 2011). Alternatively, this paper analyzes the effects of crude oil price shocks on inflation at disaggregate level for the euro area and its four main economies (France, Germany, Italy and Spain), with the objective of comparing the magnitude and timing of such effects across countries and assessing the impact on competitiveness among them. To do so, we consider the harmonized indices of consumer prices (HICPs) at aggregate and disaggregate level from January 1996 to December 2014 and multivariate transfer function models, which include-apart from crude oil—other inputs such as the price of other commodities and measures of the demand pressures that may affect the HICP. This analysis allows us to identify those goods and services that are more sensitive to crude oil price shocks, which would help for a better design of the monetary policy reactions.

In contrast to the previous studies, this paper excludes from the HICP the group of administered prices that are ruled out of market fluctuations and might distort the results. Moreover, unlike the recent literature that states that oil price should be considered endogenous with respect to macroeconomic variables (see, e.g., Kilian 2008; Hamilton 2009a; Kilian 2014), our multivariate transfer function models consider crude oil price as an input and, consequently, as an exogenous variable (Sect. 3 tests for it). This consideration may be explained by the fact that the economies considered here do not have enough size to influence the global crude oil price.

The remainder of the paper is structured as follows. Section 2 is devoted to the literature review. Section 3 describes data. Section 4 describes the methodology. Section 5 presents the main results. Section 6 concludes.

\section{Literature review}

The empirical literature about the effects of oil price shocks at disaggregate level is very limited. Whereas Edelstein and Kilian (2009) assess the effects of crude oil price shocks on consumers based on disaggregated data for personal consumption expenditures in the U.S., Bachmeier and Cha (2011) use sectoral U.S. data to evaluate the factors that may explain the decline in the impact of crude oil shocks on U.S. inflation from the mid-1980s onwards. This paper tries to extend the empirical literature on this issue by analyzing how a crude oil price shock is permeated through the components of HICP inflation across the main European countries and in the euro area as a whole.

The debate about aggregation versus disaggregation in economic modeling started with Theil (1954) and Grunfeld and Griliches (1960). Whereas Theil (1954) argues that a disaggregated modeling approach improves the model specification of 
the aggregate, Grunfeld and Griliches (1960) indicate that aggregation is not necessarily bad given that the "aggregation error" might be lower than the "specification error" derived from micro equations. Later, the literature has been developed on deriving the nature of the data generating process (DGP) of the aggregated process when it is assumed that the subcomponents follow a certain DGP (see, e.g., Lippi and Forni 1990; Nijman and Sentana 1996) and on the impact of aggregation on forecasting accuracy (see Pesaran et al. 1989; Benalal et al. 2004; Hubrich 2005). However, there is no clear answer regarding the relative forecast accuracy of the disaggregate approach versus the aggregate one.

Focusing on inflation, there is a branch of the literature that studies the role played by aggregation of disaggregate prices in explaining for the persistence of inflation. For example, Clark (2006) investigates the persistence of U.S. disaggregate consumer price inflation, observing that average disaggregate persistence is actually as great as aggregate inflation persistence. A similar result is found for the euro area by Altissimo et al. (2009). Moreover, there are some authors such as Espasa et al. (2002), Espasa and Albacete (2007) and Espasa and Mayo-Burgos (2013) that argue that in a variable such as inflation, all data -aggregate and components- matter for policy and investment decisions, and they focus on modelling and forecasting both aggregate and disaggregates. Hubrich (2005) for the euro area inflation and Hendry and Hubrich (2011) for the U.S. inflation conclude that the accuracy of inflation forecasts of the aggregate versus disaggregate approach is an empirical matter and depends on the noise and volatility of the disaggregated series. Therefore, this paper considers both approaches (aggregate and disaggregate approaches).

There is a widespread agreement in the recent literature that oil price should be considered endogenous with respect to macroeconomic aggregates, especially with respect to the U.S. output growth and inflation (see, e.g., Kilian 2008, 2014; Hamilton 2009b). Thus, it is standard in the related literature to estimate a vector autoregressive (VAR) model to study the relationship between oil prices and macroeconomic variables (see, e.g., Hamilton 1983; Jiménez-Rodríguez and Sánchez 2005; Kilian 2009; Blanchard and Galí 2010; Mandal et al. 2012). Due to the predeterminedness of oil prices with respect to the U.S. macroeconomic variables in monthly data (Kilian and Vega 2011), the bivariate VAR has been widespread used in the literature with oil price ordered first. ${ }^{1}$ In contrast with this literature, this paper finds that the null hypothesis of exogeneity of oil price changes to inflation cannot be rejected in the euro area and its main economies (see Sect. 3) and, consequently, we rely on multiple transfer function models with oil price as one of the exogenous inputs.

There is another strand of the literature about the impact of oil price shocks on inflation that adopts a Phillips curve framework (see, e.g., DeGregorio et al. 2007; Chen 2009), in which inflation is explained by its own past, the output gap and oil price changes. While DeGregorio et al. (2007) do not show the estimates for the output gap, Chen (2009) finds that the effects of output gap on inflation are small

\footnotetext{
1 It is worth noting that large structures of VARs can be problematic because they need additional identification assumptions for impulse response analysis.
} 
and not statistically significant for the countries considered in our paper (France, Germany, Italy and Spain). This result motivates us not to use the output gap as an explanatory variable in our regressions. Furthermore, other potential explanatory variable could be a monetary policy measure, but Chen (2009) finds that any monetary policy measure considered (Taylor rule, change in interest rates and change in M2) is not statistically significant to explain the oil price pass-through into inflation.

As regards the stability of the relations, the recent literature proposes the use of time-varying parameter models to relate oil shocks to other variables in the economy (see, e.g., Baumeister and Peersman 2013a, b; Bekiros et al. 2015; Bekiros and Paccagnini 2016; Riggi and Venditti 2015). However, Blanchard and Galí (2010) point out that the date where there are large changes in the effects of an oil price shock on real activity and prices is before and after the mid-1980s. Thus, it does seem reasonable to consider time-invariant parameters given that our sample starts in 1996 (due to data availability).

\section{Data}

\subsection{Preliminary considerations}

In this subsection, we describe the evolution of prices referred to the monthly HICP for the euro area $^{2}$ and its main economies (France, Germany, Italy and Spain) during the sample period running from January 1996 to December $2014 .^{3}$ These data come from Eurostat (http://ec.europa.eu/eurostat/data/databasehttp://ec.europa.eu/ eurostat). ${ }^{4}$

Table 1 shows a simple descriptive analysis of the accumulated energy and nonenergy inflation and their contributions in percentage points to total inflation for the euro area and its main economies. ${ }^{5}$ We observe that the accumulated energy inflation has been larger than the non-energy component for all economies although there are some differences across them. Whereas the accumulated energy inflation has been about 4 times larger than the non-energy inflation in Germany, it has been less than 2 times larger in Italy and Spain and a bit more than the double in the euro area. Moreover, the non-energy group presents the greatest contributions to the total

\footnotetext{
${ }^{2}$ Euro area HICPs are calculated as weighted averages of HICPs of its members. Country weights are computed every year reflecting the country's share of private final consumption expenditure (see http://ec. europa.eu/eurostat/data/database). The four countries considered here represent $78 \%$ of total weights.

${ }^{3}$ It is worth noting that HICPs are monthly price indices designed for international comparison of consumer price inflation.

4 The first date available in Eurostat is 1996. That is why our sample starts in such a year.

5 The accumulated inflation is defined as the price increase (expressed as percentages) between two time periods, in our case, 1996:01 and 2014:12. Energy HICP group includes electricity, gas, liquid fuels, and fuels and lubricants for personal transport equipment. Contributions are referred to accumulated inflation multiplied by its corresponding weights in total HICP. Mean weights of energy for the period 1996-2014 are: $9.4 \%$ for the euro area, $8.9 \%$ for France, $10.8 \%$ for Germany, $7.5 \%$ for Italy, and $9.4 \%$ for Spain.
} 
Table 1 Accumulated inflation (\%), and contributions of Energy and Non-energy inflation to total (percentage points), 1996:01-2014:12

\begin{tabular}{llcllcc}
\hline & \multicolumn{2}{l}{ Accumulated inflation } & & \multicolumn{2}{l}{ Contributions, percentage points } \\
\cline { 2 - 3 } & Total & Energy & Non-energy & & Energy & Non-energy \\
\hline Euro area & 40.66 & 92.83 & 37.35 & & 8.69 & 33.86 \\
Germany & 32.31 & 101.83 & 28.06 & & 10.95 & 25.04 \\
France & 34.74 & 73.57 & 32.34 & & 6.57 & 29.45 \\
Italy & 48.88 & 74.9 & 47.23 & & 5.62 & 43.69 \\
Spain & 56.7 & 98.66 & 52.87 & & 9.29 & 47.89
\end{tabular}

Contributions are referred to accumulated inflation multiplied by its corresponding weights in total HICP. There are some differences in total inflation when adding up energy and non-energy contributions due to changes in weights

Germany
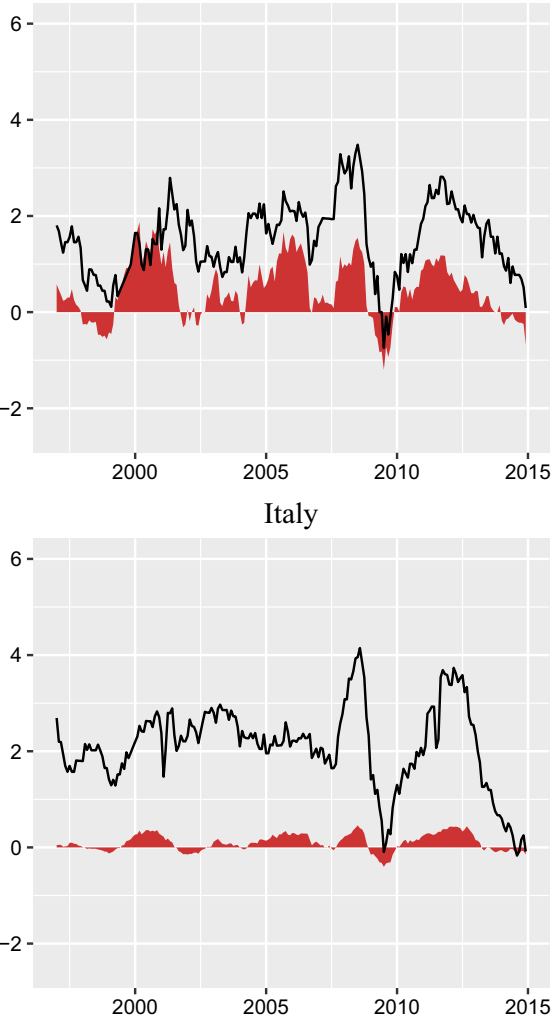

France
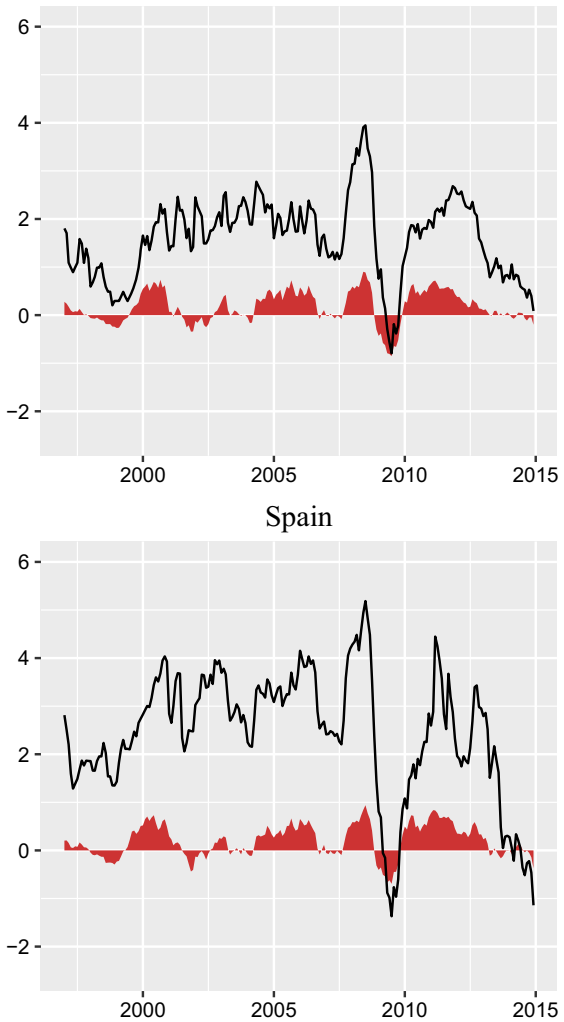

Note: The black line depicts the annual inflation in percentage. The red shaded areas correspond to energy contributions. Data source: Eurostat.

Fig. 1 Contributions of energy and non-energy groups to annual inflation (\%), 1997:1-2014:12 
inflation in all economies, with contributions being around 30 percentage points in Germany and France and larger in the rest of economies.

Figure 1 illustrates the contribution of the energy group to the total annual inflation over time. As expected, the energy group has contributed notably to inflation fluctuations in all countries, especially in Germany.

In an attempt to better understand these differences among European countries, we consider the energy consumption structure, ${ }^{6}$ taxes and regulations in domestic energy markets, as well as the role of administered inflation. On the one hand, the left panel of Fig. 2 shows that Germany has the smallest share of petroleum products with respect to the total final national energy consumption between 1996 and 2012 and Spain has the largest one, while France and Italy show relatively similar behavior to Germany. The right panel of Fig. 2 shows that the percent of consumption of fuels for personal transport (the item probably with more direct effects from an oil price shock) accounted for $6-7 \%$ for Spain and about $4 \%$ for the other countries in the 2010s. On the other hand, Fig. 3 also shows the different taxation structure in two of the most important petroleum products for consumption (euro-super 95 and diesel oil) among countries, with Germany and France showing the highest taxation, as opposed to Spain, with the lowest one. These key facts suggest that variations in the price of petroleum products may have greater effects in Spain than in Germany.

Additionally, there are different regulations for the price of the remaining energy consumption products and services (mainly, gas and electricity) in the four countries considered. These regulations can be affected by political considerations, among others. In order to do a more homogeneous comparison, we have decided to exclude from our analysis all goods and services classified as administered (therefore, not directly open to market fluctuations) by Eurostat.

\subsection{Data description}

We work with a set of 58 subclasses of non-administered price indices (aggregate in five groups: processed food, non-energy industrial goods, services, unprocessed food and energy) for the euro area and its main economies (France, Germany, Italy and Spain), using Eurostat data from January 1996 to December 2014. ${ }^{7}$

Table 2 presents the weights, in percentage, of administered goods and services excluded from total HICP. We observe that the total weight excluded from HICP ranges from $23.4 \%$ in Italy to $30.7 \%$ in Germany, and is mainly concentrated in services. ${ }^{8}$ The most important services excluded are telephone, waste collection,

\footnotetext{
${ }^{6}$ According to Eurostat, the weights for the HICP sub-indices are "the aggregate expenditure by households on any set of goods and services covered by the HICP, expressed as a proportion of the total expenditure on all goods and services within the coverage of the HICP." For more details see Eurostat (http://ec.europa.eu/eurostat).

7 Eurostat reports 93 subclasses of price indices, but we have excluded the goods and services with totally or partially administered prices according to the Eurostat criterion. When some of them are administered in one region but not in another, we exclude the corresponding prices in both in order to obtain the highest level of comparison.

8 There are not administered prices in the group of unprocessed food.
} 

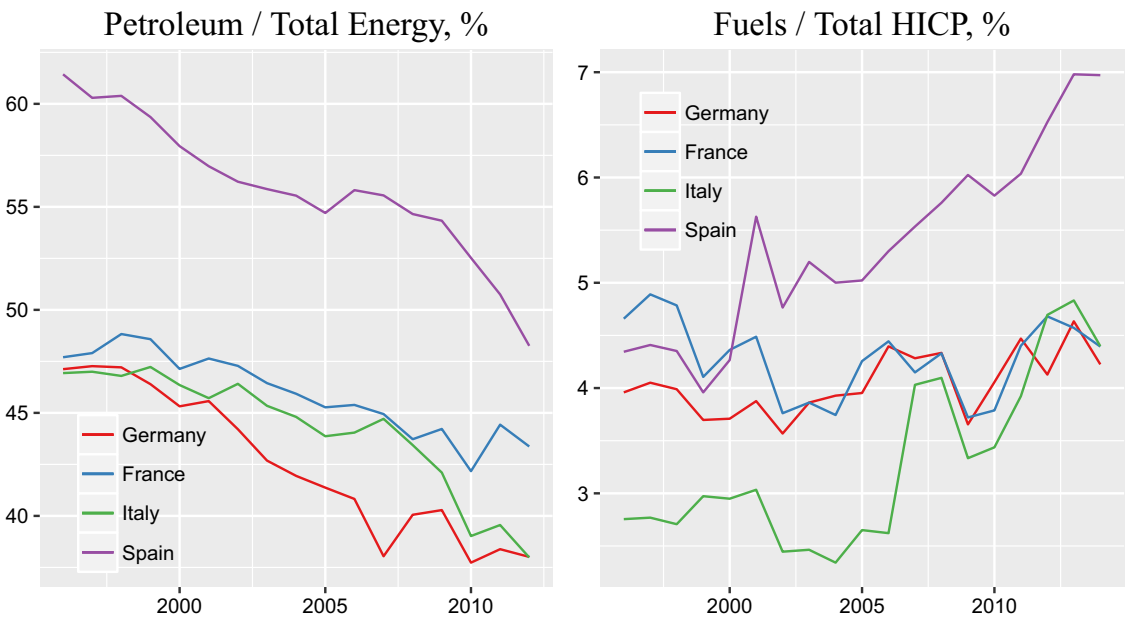

Note: Petroleum refers to LPG, gasoline, kerosen and gas/diesel oil consumption. Fuels refer to expenditure in fuels and lubricants for personal transport equipment. Data source: European Commission and Eurostat.

Fig. 2 Share of consumption for petroleum in total energy (1996-2012) and fuels in total HICP (1996-2014)
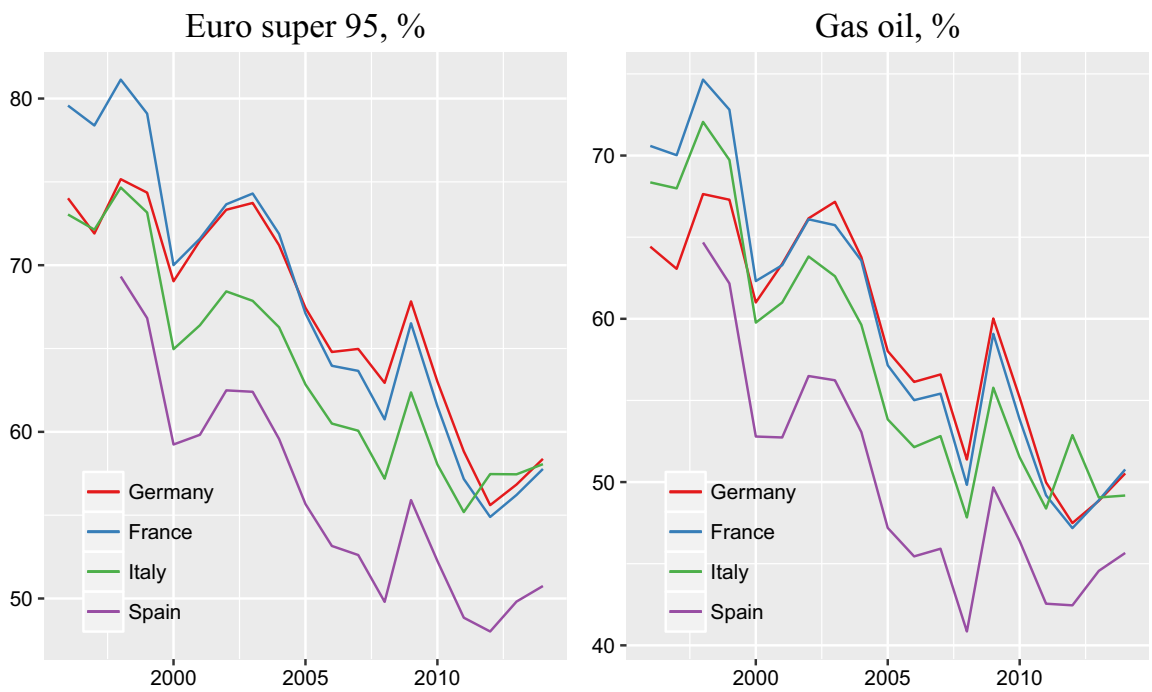

Data source: European Commission.

Fig. 3 Total taxation share $(\%)$ in the final consumer price of gasoline (Euro-super 95) and gas oil; 1996-2014

cultural services, combined passenger transport and education. In the energy sector, we exclude solid fuels and heat energy, which are administered prices only in Germany and France, but we exclude them in the remaining regions for 
Table 2 Weights (\%) of administered goods and services excluded from total HICP

\begin{tabular}{lcccrr}
\hline & Euro area & Germany & France & Italy & Spain \\
\hline Processed-food & 2.4 & 2.5 & 2.3 & 2.3 & 2.0 \\
Non-energy industrial goods & 3.5 & 4.3 & 3.3 & 2.9 & 3.5 \\
Services & 15.6 & 17.4 & 14.8 & 13.6 & 13.6 \\
Energy & 5.2 & 6.5 & 4.6 & 4.5 & 4.8 \\
Total & 26.7 & 30.7 & 25.0 & 23.4 & 23.9 \\
\hline
\end{tabular}

Table 3 Accumulated non-administered inflation (\%), and contributions of Energy and Non-energy inflation to total (percentage points), 1996:01-2014:12

\begin{tabular}{lllllll}
\hline & \multicolumn{3}{l}{ Accumulated inflation, $\%$} & & \multicolumn{2}{l}{ Contributions, percentage points } \\
\cline { 2 - 3 } & Total & Energy & Non-energy & & Energy & Non-energy \\
\hline Euro area & 37.26 & 95.12 & 33.85 & & 6.13 & 31.67 \\
Germany & 26.07 & 88.06 & 22.38 & & 5.98 & 22.04 \\
France & 32.51 & 83.66 & 29.44 & & 5.34 & 27.26 \\
Italy & 48.94 & 82.51 & 46.99 & & 5.13 & 42.37 \\
Spain & 53.68 & 106.98 & 49.78 & & 6.57 & 44.39
\end{tabular}

Contributions are accumulated non-administered inflation multiplied by its corresponding weights in total HICP. There are some differences in total inflation when adding up energy and non-energy contributions due to changes in weights

homogeneous aggregation. We also exclude electricity and gas, which are fully or mainly administered in all economies.

Table 3 shows the behavior of non-administered inflation. There are some differences with respect to inflation shown in Table 1. First, non-administered accumulated inflation is smaller in the euro area and Germany, which indicates that administered inflation has been positive and has helped to increase inflation pressures. These differences are mainly attributable to the excluded administered prices of gas and electricity. Second, energy contributions to total non-administered inflation are much smaller in all economies. Finally, non-energy inflation is highly similar to inflation including administered prices.

Therefore, we consider non-administered disaggregate inflation to analyze the effects of oil price shocks and we will refer, hereafter, to non-administered inflation as inflation.

While the contribution of the energy component to inflation seems to be, on average, slightly smaller when non-administered prices are considered (see Table 3), energy inflation seems to be an important determinant for total inflation, especially in Germany and France (see Fig. 4). The energy component seems to be less 

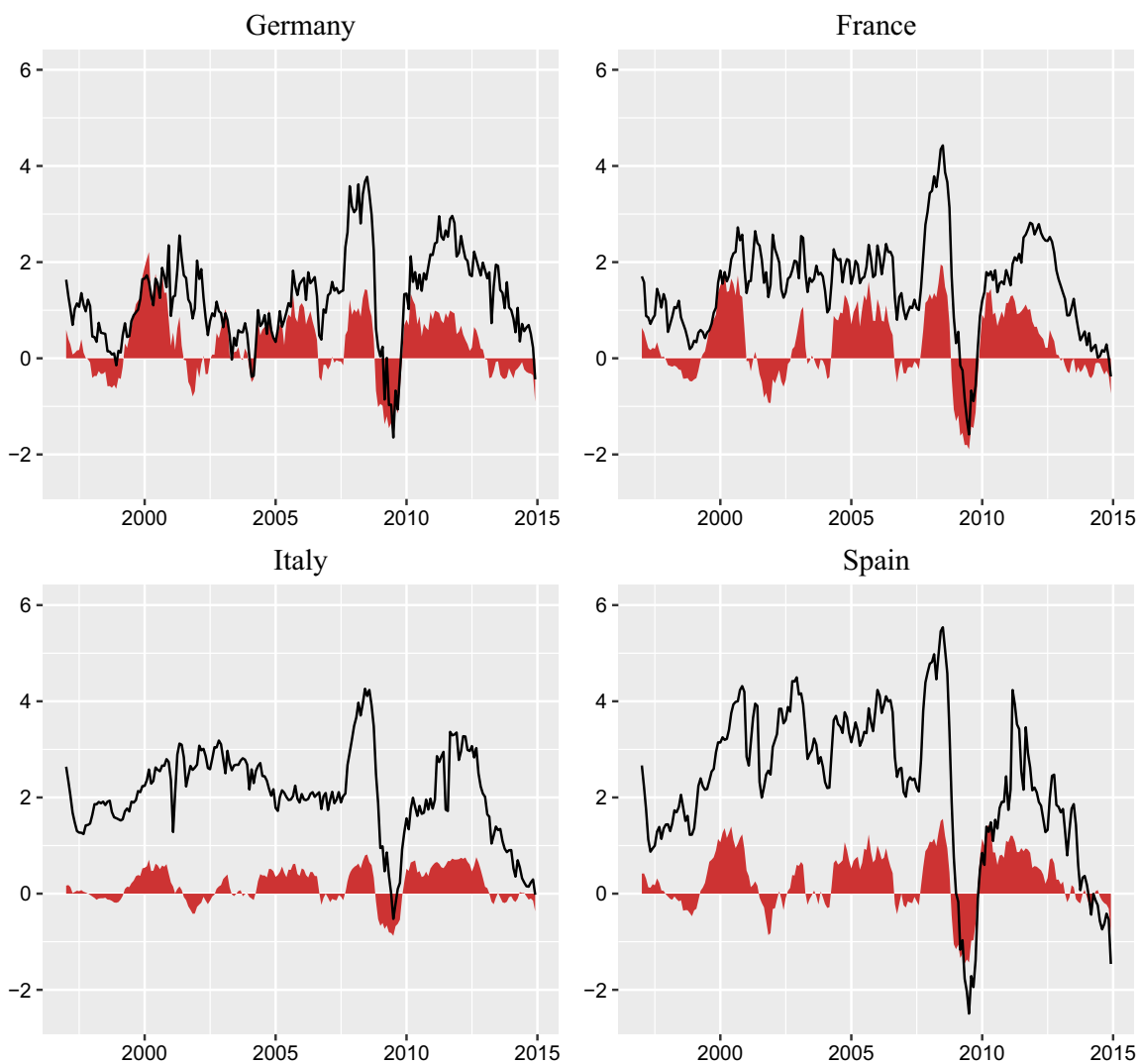

Note: The black line depicts the annual inflation in percentage. The red shaded areas correspond to energy contributions. Data source: Eurostat.

Fig. 4 Contributions of energy and non-energy groups to annual inflation, excluding administered prices (\%), 1997.1-2014.12

important in Spain and Italy (countries where total inflation appears to be dominated by other factors) although it has played a relevant role during some periods.

\subsection{Granger causality tests}

It seems reasonable to think that global oil prices may depend on the U.S. macroeconomic variables such as GDP growth and inflation. However, it seems less reasonable to consider that each component of aggregate inflation may have an influence in the evolution of global oil prices and less in countries like those considered in this paper.

To investigate the latter assertion, we perform a test for linear Granger (G)causality in bivariate stationary series evaluating whether the past values of inflation, $P_{t}^{i}$, help predicting the value of oil price changes, $O_{t}$, at aggregate and disaggregate level for the corresponding $i$ economy (the euro area, Germany, 
France, Italy and Spain). Additionally, we also test for linear G-causality from oil price changes to inflation at aggregate and disaggregate level.

We first study the seasonal and non-stationary behavior of the log transformed variables. As expected, all of the consumer price indices in these economies display seasonality, originated especially in the behavior of non-energy industrial goods. On the contrary, oil prices do not have seasonal fluctuations. Therefore, we perform a seasonal adjustment procedure to consumer price indices using the TRAMOSEATS. ${ }^{9}$

Once the consumer price indices have been seasonally adjusted, we analyze the stationarity of the log levels of oil prices and consumer prices by using the augmented Dickey-Fuller test (ADF, Ho: unit root exists). We obtain that we cannot reject the null hypothesis for any variable. Thus, we analyze the first differences of the variable (in logarithms) in order to establish the order of integration and we obtain that all variables (in first log differences) are stationary. Table 4 shows the ADF test statistics for the log levels and difference of the variables.

Once we have determined how each variable has to be considered, we implement the $\mathrm{G}-$ causality test. We perform a bivariate test for each inflation against oil price changes: ${ }^{10}$

$$
\begin{gathered}
P_{t}^{i}=c^{i, 1}+\sum_{j=1}^{p} \alpha_{j}^{1} P_{t-j}^{i}+\sum_{j=1}^{p} \beta_{j}^{1} O_{t-j}+\mu_{t}^{i, 1} \\
O_{t}=c^{2}+\sum_{j=1}^{p} \alpha_{j}^{2} O_{t-j}+\sum_{j=1}^{p} \beta_{j}^{2} P_{t-j}^{i}+\mu_{t}^{2}
\end{gathered}
$$

for $p=1,2, \ldots 24$ and $i \in\{$ euro area, Germany, France, Italy, Spain $\}$. The null hypothesis for Eq. 1 is that $p$ lags of $O_{t}$ do not help in predicting value of $P_{t}^{i}$, and for Eq. 2 is that $p$ lags of $P_{t}^{i}$ do not help in predicting value of $O_{t}$. In particular, we use an $F$-test to determine whether jointly $\beta_{j}^{k}$ are zero:

$$
\text { Ho : } \quad \beta_{1}^{k}=\beta_{2}^{k}=\ldots \beta_{p}^{k}=0 \quad \text { with } \quad \mathrm{k}=1,2
$$

Instead of evaluating the G-causality test for a convenient $p$ lag, we consider the warning of Hamilton and Herrera (2004) about the convenience of including a rich lag structure in studying the effects of oil prices on macroeconomic variables. Then, we investigate the sensitivity of the G-causality test to the choice of lag length $p=1,2, \ldots 24$, calculating their corresponding $p$-values. Figure 5 shows that $O_{t} \mathrm{G}$-causes $P_{t}^{i}$ in all economies for most lags. However, Fig. 6 indicates that inflation does not G-cause oil price changes for the euro area and most of the individual countries. In fact, we do not find evidence of G-causality from inflation to oil price changes in the euro area, France, Italy and Spain, although there is some evidence for Italy $(p=1)$ and Germany (at

\footnotetext{
9 We implement the multi processing seasonal adjustment with JDemetra+, available at European Statistical System: http://ec.europa.eu/eurostat/web/ess/-/jdemetra-officially-recommended-as-softwarefor-the-seasonal-adjustment-of-official-statistics.

${ }^{10}$ As expected, we obtain similar results with the block exogeneity Granger test for a fitted VAR.
} 
Table 4 ADF test statistics for $\log$ levels and differences $(\nabla)$

\begin{tabular}{lccc}
\hline & Levels & $\nabla$ & \\
\hline$P_{t}^{\text {oil }}$ & -2.57 & -9.11 & $* * *$ \\
$H I C P_{t}^{\text {E.A. }}$ & -0.77 & -7.60 & $* * *$ \\
$\mathrm{HICP}_{t}^{\text {Germany }}$ & -2.10 & -9.85 & $* * *$ \\
$\mathrm{HICP}_{t}^{\text {France }}$ & -1.67 & -9.76 & $* * *$ \\
$\mathrm{HICP}_{t}^{\text {Italy }}$ & 0.72 & -7.14 & $* * *$ \\
HICP $_{t}^{\text {Spain }}$ & 1.16 & -7.91 & $* * *$ \\
\hline
\end{tabular}

$1 \%$ levels, respectively

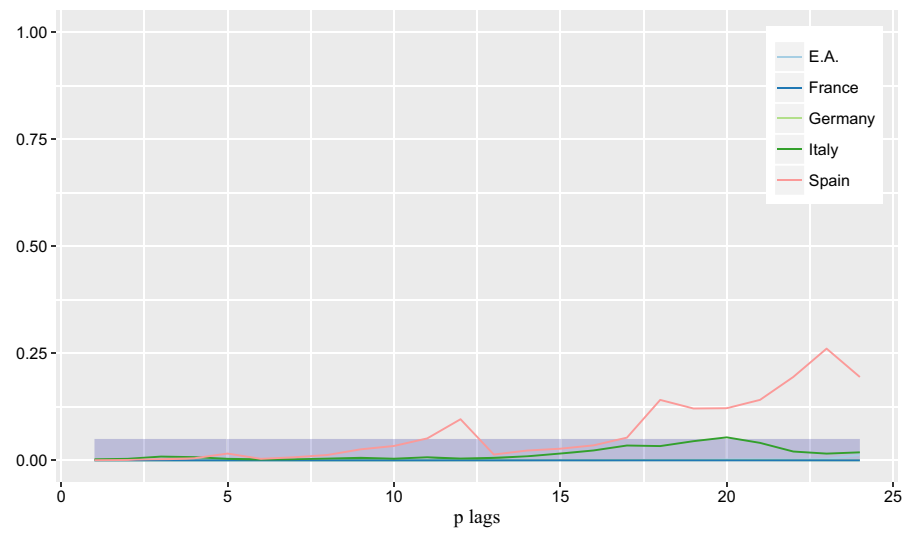

Note: This figure shows the $\mathrm{p}$-value for the $\mathrm{G}-$ causality test whose null hypothesis is that $\mathrm{O}_{\mathrm{t}}$ does not $\mathrm{G}$-cause $\mathrm{P}_{\mathrm{t}}^{\mathrm{i}}$ with lags $\mathrm{p}=1,2, \ldots, 24$. $\mathrm{p}$-value $<0.05$ (shaded area) rejects the null hypothesis.

Fig. $5 p$ values for G-causality test whose null hypothesis is that $O_{t}$ does not G-cause $P_{t}^{i}$

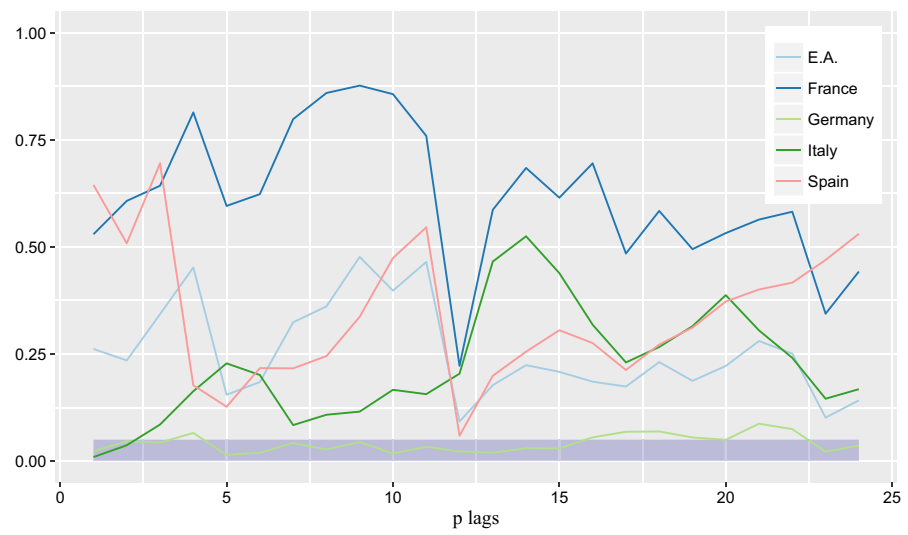

Note: This figure shows the $\mathrm{p}$-value for the $\mathrm{G}-$ causality test whose null hypothesis is that $\mathrm{P}_{\mathrm{t}}^{\mathrm{i}}$ does not $\mathrm{G}$-cause $\mathrm{O}_{\mathrm{t}}$, with lags $\mathrm{p}=1,2, \ldots, 24$. $\mathrm{p}$-value $<0.05$ (shaded area) rejects the null hypothesis.

Fig. $6 p$-values for G-causality test whose null hypothesis is that $P_{t}^{i}$ does not G-cause $O_{t}$ 
different lags). We examine in more detail the latter result by using the nonparametric G-causality test (see Diks and Panchenko 2006), and we observe that there is no evidence that German inflation G-causes oil price changes (see Fig. 7). ${ }^{11}$

We extend the preliminary analysis to 58 non-administered goods and services of HICP for Germany, France, Italy, Spain and the euro area. We find that all inflation series in the five economies (except milk, cheese and eggs in Italy and non-durable household goods in the euro area) have a seasonal component and therefore they were seasonally adjusted by using TRAMO-SEATS. Regarding the presence of unit roots in these series, we cannot reject the null hypothesis of the existence of a unit root for most of the logarithms of variables (see Table 5), but the first differences of the logarithms of the variables are clearly stationary (see Table 6). ${ }^{12}$ Finally, we perform the G-causality test for the stationary variables. Table 7 presents the $p$ values for the null hypothesis that inflation of corresponding good/service $j$, in economy $i, P_{t}^{i, j}$ does not G-cause $O_{t}$ at $p=12$. In general, we do not reject the null hypothesis and so inflation at disaggregate level does not seem to help in predicting oil price changes. ${ }^{13}$

Therefore, it seems reasonable not to consider oil price as an endogenous variable in the context of a disaggregated analysis of macroeconomic variables for the euro area and its main economies.

\section{Methodology}

To analyze how crude oil price increases are translated into inflation in the euro area and its main economies, we estimate a set of multivariate transfer function (TF) models for 58 subclasses of inflation. As has been mentioned in the Introduction, higher oil prices have impacts on consumers through both the direct first-round effects by reducing their demand for goods and services as a consequence of a lower disposable income due to more expensive energy bills and the second-round effects by modifying their consumption plans due to changes in their expectations. Also, higher oil prices have impacts on producers through both the indirect effects, by increasing production costs, and the second-round effects, by varying their production and their investment plans due to the changes in the producers' expectations about the consumers' reactions. This paper follows this line of reasoning by considering a set of control variables related with demand and supply side. On the demand side, we assume that potential consumer's reaction would depend on the domestic and global economic environment and so we use the consumer confidence indicator and international trade measures, respectively. On

\footnotetext{
11 We have also applied the nonparametric G-causality test for Italy when $p=1$. The Diks-Panchenko test equals 1.369 ( $p$-value: 0.91451). Thus, there is no evidence that inflation G-causes oil price changes.

12 Although few variables are stationary in log levels, we also use them in first-differences to facilitate the interpretation of the results.

13 Although there are very few rejections at the greatest disaggregate level, we will assume that oil price is also exogenous for these cases.
} 


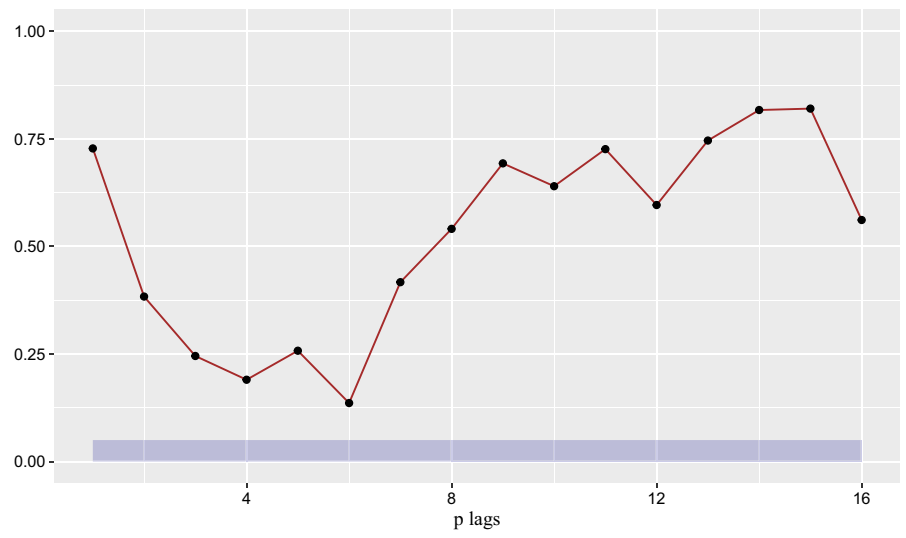

Note: This figure shows the $\mathrm{p}-$ value for the non-parametric $\mathrm{G}-$ causality test whose null hypothesis is that $\mathrm{P}_{\mathrm{t}}^{\mathrm{Germany}}$ does not $\mathrm{G}$-cause $\mathrm{O}_{\mathrm{t}}$ with lags $\mathrm{p}=1,2, \ldots, 24$. $\mathrm{p}$-value $<0.05$ (shaded area) rejects the null hypothesis.

Fig. $7 p$-values for non-parametric G-causality test whose null hypothesis is that $P_{t}^{\text {Germany }}$ does not Gcause $O_{t}$

the supply side, we consider that other generic raw materials used in the production process, apart from crude oil, may have an impact on prices and that is why we include the non-fuel price index in our model. ${ }^{1}$

The TF model for the inflation of good/service $j$, in economy $i, P_{t}^{i, j}$ with $i=1, \ldots, 5$, and $j=1, \ldots, 58$, is written ${ }^{15}$

$$
\begin{gathered}
P_{t}^{i, j}=c^{i, j}+v(L) x_{t}^{i}+N_{t}^{i, j} \\
v(L)=\left(v^{1}(L), v^{2}(L), v^{3}(L), v^{4}(L)\right) \\
v^{k}(L)=v_{0}^{k}+v_{1}^{k} L+v_{2}^{k} L^{2}+\cdots+v_{12}^{k} L^{12} \\
x_{t}^{i}=\left(O_{t}, N C_{t}, S_{t}^{i}, T_{t}\right)^{\prime}
\end{gathered}
$$

where $L$ is the lag operator, $c^{i, j}$ is the constant, $O_{t}$ is oil price changes, $N C_{t}$ is nonenergy commodity price changes, $S_{t}^{i}$ is the change in the consumer confidence indicator, $T_{t}$ is the growth of the international trade index, and $N_{t}^{i, j}$ is the disturbance term. Note that the input and output variables are stationary. ${ }^{16}$

\footnotetext{
${ }^{14}$ The exchange rate could be another potential explanatory variable. However, we find that the exchange rates of domestic currency for each country against U.S. dollar are highly correlated and the correlation between the exchange rates and international trade index are relatively high correlated for all countries as a referee suggests. Thus, the potential effects of exchange rates in our regressions seem to be well captured by including the international trade index.

${ }^{15} \mathrm{We}$ adjust for outliers (when they show up) in the estimation by means of impulse dummies.

${ }^{16} \mathrm{We}$ perform the ADF test ( $p$-values in parenthesis) for log levels of non-energy commodity price (0.41), consumer confidence indicator (Germany: 0.113, France: 0.073, Italy: 0.436, Spain: 0.315 ) and international trade index (0.018), and conclude that we should employ the first log-differences to achieve stationary.
} 
Table 5 ADF test statistics for log levels of HICP of goods and services

\begin{tabular}{|c|c|c|c|c|c|}
\hline & Euro area & Germany & France & Italy & Spain \\
\hline Bread and cereals & -2.39 & -1.82 & -0.52 & -2.06 & -0.46 \\
\hline Milk, cheese and eggs & $-3.51 * *$ & -2.54 & -2.49 & -2.14 & -2.10 \\
\hline Oils and fats & $-3.73 * *$ & -2.37 & $-3.14 *$ & -2.43 & $-3.55^{* *}$ \\
\hline $\begin{array}{l}\text { Sugar, jam, honey, chocolate and } \\
\text { confectionery }\end{array}$ & -2.14 & -2.25 & -0.52 & -2.08 & -0.49 \\
\hline Food products n.e.c. & -0.82 & -1.80 & 1.00 & -1.14 & -2.43 \\
\hline Coffee, tea and cocoa & -1.47 & -0.89 & -2.81 & -1.52 & -1.90 \\
\hline $\begin{array}{l}\text { Mineral waters, soft drinks, fruit and } \\
\text { vegetable juices }\end{array}$ & -2.24 & -1.96 & -1.28 & -0.94 & -1.10 \\
\hline Spirits & -0.60 & -1.58 & -0.83 & -1.34 & -2.32 \\
\hline Wine & -1.24 & -0.56 & -1.40 & $-3.72 * *$ & -1.64 \\
\hline Beer & -2.10 & -2.36 & -2.58 & 0.38 & $-3.66 * *$ \\
\hline Furniture and furnishings & 1.12 & -2.05 & -2.25 & 0.84 & 3.36 \\
\hline Carpets and other floor coverings & -1.25 & $-3.99 * * *$ & -2.24 & -2.90 & -0.81 \\
\hline Major, small household appliances & -0.02 & -0.93 & -2.21 & -2.63 & 0.58 \\
\hline Motor cars & -0.26 & -1.07 & $-3.14 *$ & $-3.91 * * *$ & -1.39 \\
\hline $\begin{array}{l}\text { Motor cycles, bicycles and animal drawn } \\
\text { vehicles }\end{array}$ & -1.34 & -1.53 & -1.78 & $-3.62 * *$ & -2.06 \\
\hline $\begin{array}{l}\text { Equip. reception, recording and rep. } \\
\text { sound and pictures }\end{array}$ & -2.24 & -2.02 & -2.04 & -1.34 & -2.43 \\
\hline $\begin{array}{l}\text { Phot. and cinematographic equipment and } \\
\text { optical inst. }\end{array}$ & -2.82 & -2.35 & -1.56 & -1.73 & -2.43 \\
\hline Information processing equipment & 0.32 & 0.72 & 1.32 & -2.28 & -2.00 \\
\hline Jewellery, clocks and watches & -2.22 & -1.56 & -2.53 & -2.32 & -1.80 \\
\hline Garments & $-5.20 * * *$ & 0.61 & $-4.68 * * *$ & -3.04 & $-3.61 * *$ \\
\hline $\begin{array}{l}\text { Other articles of clothing and clothing } \\
\text { accessories }\end{array}$ & $-3.19 *$ & -1.43 & $-5.68 * * *$ & -1.51 & -1.03 \\
\hline Footwear including repair & -2.25 & -0.20 & $-3.20^{*}$ & -2.46 & -1.22 \\
\hline Household textiles & -1.45 & 0.32 & -1.58 & -1.92 & 1.07 \\
\hline $\begin{array}{l}\text { Glassware, tableware and household } \\
\text { utensils }\end{array}$ & -0.33 & -0.44 & 0.51 & 0.09 & 0.06 \\
\hline $\begin{array}{l}\text { Tools and equipment for house and } \\
\text { garden }\end{array}$ & $-3.16^{*}$ & -0.71 & -2.37 & 0.74 & 0.87 \\
\hline $\begin{array}{l}\text { Spares parts, accessories for personal } \\
\text { transport equip. }\end{array}$ & $-3.43 * *$ & -1.83 & $-4.01 * * *$ & -1.65 & -2.56 \\
\hline Recording media & -2.14 & $-3.38^{*}$ & -2.33 & -2.72 & 1.06 \\
\hline Games, toys and hobbies & -2.71 & -2.24 & -3.10 & $-4.34 * * *$ & -0.95 \\
\hline $\begin{array}{l}\text { Equipment for sport, camping and } \\
\text { open-air recreation }\end{array}$ & -0.78 & -0.05 & -2.66 & -1.66 & 1.60 \\
\hline Other personal effects & -1.01 & -2.43 & -1.73 & $-3.16^{*}$ & -1.43 \\
\hline $\begin{array}{l}\text { Materials for the maintenance and repair } \\
\text { of the dwelling }\end{array}$ & -1.64 & -1.88 & -1.78 & -0.94 & 1.31 \\
\hline Non-durable household goods & -1.40 & -0.58 & -1.22 & -2.26 & -2.35 \\
\hline Gardens, plants and flowers & $-4.35 * * *$ & -1.88 & $-4.49 * * *$ & -1.07 & -0.33 \\
\hline
\end{tabular}


Table 5 continued

\begin{tabular}{|c|c|c|c|c|c|}
\hline & Euro area & Germany & France & Italy & Spain \\
\hline $\begin{array}{l}\text { Pets and related products; veterinary and } \\
\text { other services }\end{array}$ & -2.37 & -1.54 & -2.20 & $-4.41 * * *$ & $-4.21 * * *$ \\
\hline Newspapers and periodicals & -1.50 & -0.14 & -2.27 & -1.85 & -1.64 \\
\hline $\begin{array}{l}\text { Miscellaneous printed matter; stationery, } \\
\text { drawing mat. }\end{array}$ & -1.41 & -0.97 & -0.14 & -1.10 & -2.42 \\
\hline $\begin{array}{l}\text { Electrical appliances, articles and } \\
\text { products personal care }\end{array}$ & 1.73 & 0.29 & 1.33 & -1.35 & 1.79 \\
\hline Actual rentals for housing & -1.33 & $-5.00 * * *$ & -0.60 & $-3.98 * * *$ & 1.41 \\
\hline $\begin{array}{l}\text { Services for the maintenance and repair of } \\
\text { the dwelling }\end{array}$ & -1.11 & -1.71 & -2.13 & 0.29 & 3.79 \\
\hline Repair of household appliances & -1.54 & -2.69 & -2.05 & $-3.93 * * *$ & -1.12 \\
\hline Domestic services and household services & 0.54 & $-4.77 * * *$ & -1.89 & -1.88 & 4.52 \\
\hline Recreational and sporting services & 0.59 & $-4.40 * * *$ & $-3.29 *$ & -0.28 & 1.11 \\
\hline Restaurants, cafes and the like & 1.05 & -1.63 & -1.06 & 2.44 & 2.37 \\
\hline Canteens & -2.08 & -2.99 & -1.37 & -3.07 & 2.65 \\
\hline $\begin{array}{l}\text { Hairdressing salons, personal grooming } \\
\text { establishments }\end{array}$ & 0.30 & -1.54 & -0.26 & 1.71 & 0.25 \\
\hline Package holidays & -2.71 & -1.68 & $-5.47 * * *$ & -2.39 & -2.76 \\
\hline Accommodation services & -0.97 & -1.92 & -2.88 & -1.02 & -0.69 \\
\hline $\begin{array}{l}\text { Maintenance and repair of personal } \\
\text { transport equip. }\end{array}$ & -0.15 & -1.80 & -0.73 & 1.88 & 0.25 \\
\hline $\begin{array}{l}\text { Other services in respect of personal } \\
\text { transport equip. }\end{array}$ & -0.39 & -1.40 & -1.49 & -2.42 & 0.46 \\
\hline Passenger transport by air & -2.76 & -2.21 & $-3.24 *$ & -2.88 & -2.01 \\
\hline Insurance connected with transport & -0.74 & -1.81 & -1.85 & -1.61 & 0.25 \\
\hline Financial services n.e.c. & 0.11 & 0.33 & -1.99 & -1.02 & -2.07 \\
\hline Meat & -2.85 & -1.56 & -2.40 & -1.98 & -1.04 \\
\hline Fish and seafood & -1.26 & -2.20 & -2.13 & -1.05 & -1.31 \\
\hline Fruit & -2.95 & -2.63 & $-4.40 * * *$ & -1.75 & -1.66 \\
\hline Vegetables & $-4.09 * * *$ & $-5.38 * * *$ & $-6.23^{* * *}$ & -2.21 & -2.11 \\
\hline Liquid fuels & -2.63 & -2.41 & -2.91 & $-3.26^{*}$ & -3.07 \\
\hline $\begin{array}{l}\text { Fuels and lubricants for personal transport } \\
\text { equipment }\end{array}$ & -3.10 & -2.52 & -3.06 & $-3.39 *$ & $-3.89 * * *$ \\
\hline
\end{tabular}

Ho: Unit root exists. One/two/three asterisks denote significance at the $10 \%, 5 \%$ and $1 \%$ levels, respectively. All test results are based on $p=12$ lags

We consider the nominal price of Brent in $€$ per barrel (henceforth, Brent, downloaded from the U.S. Energy Information Administration web page, http:// www.eia.gov) as a measure of international price of oil. ${ }^{17} \mathrm{We}$ use the nominal non-

\footnotetext{
17 We work with the oil price nominated in euros because it is the reference price for European consumers. Nonetheless, our results come from the analysis of the first differences of the series with seasonal treatment, so the gains of transfer functions would not change if we use the oil price nominated in euros or dollars (see, Castro et al. 2016).
} 
fuel price index in $€$, which includes price indices of food and beverages and industrial inputs, as non-energy commodity prices. These data come from the International Monetary Fund (http://www.imf.org). The consumer confidence indicator for each economy comes from the European Commission (http:// www.ec.europa.eu). This indicator measures the level of optimism that consumers have about the economy and is the result of a monthly consumer survey about their financial and general economic situation, unemployment expectations and savings over next 12 months. Finally, we consider the index of worldwide monthly data on international trade provided by the CPB Netherlands Bureau for Economic Policy Analysis (http://www.cpb.nl). ${ }^{18}$

The effects of each input $k \in\{1, \ldots, 4\}$ are represented with the linear TF operator $v^{k}(L)$, where the values $v_{0}^{k}, v_{1}^{k}, \ldots, v_{12}^{k}$ are referred to the impulse response $\mathrm{TF}$ weights and represent the delay of response in the process within a year. These weights provide a measure of how the input variables affect the inflation at each time lag. The sum of all weights $g_{k}=v_{0}^{k}+v_{1}^{k}+\cdots+v_{12}^{k}$ is called the steady state gain (see Liu et al. 1992). ${ }^{19}$ As our objective is to check how $O_{t}$ is transmitted dynamically into the HICP inflation, we are interested in calculating from Eq. 3 the steady state gain for $k=1, g_{1}$.

Finally, the disturbance term $N_{t}^{i, j}$ is normally considered to be a stationary ARMA process defined as

$$
N_{t}^{i, j}=\frac{\theta(L)}{\phi(L)} a_{t}^{i, j}
$$

where $\phi(L)$ is the autoregressive operator of order $p$ and $\theta(L)$ the moving average process of order $q . a_{t}^{i, j}$ is a sequence of random errors that are independently and identically distributed with a normal distribution $N\left(0, \sigma_{a^{i, j}}^{2}\right)$.

The TF has been specified by the Linear Transfer Function (LTF) identification method, proposed by Liu and Hanssens (1982). All the calculations have been implemented in SCA statistical system software (Liu et al. 1992).

\section{Results}

We first obtain the steady state gain in percentage points derived from a $10 \%$ oil price increase for total inflation (see Table 8 , first column). ${ }^{20}$ This gain is around 0.16 percentage points for all economies except for Italy where no gain is observed.

\footnotetext{
18 There are other variables used to measure global demand growth as the Industrial Production or the Kilian (2009) monthly global real activity index, but the results are similar. The CPB index of international trade is an instrument for bringing together, aggregating, and summarizing worldwide monthly data on international trade. Its purpose is to report monthly developments in trade at the earliest possible date, covering a sample of countries as large as possible.

19 In our case, the weights are only considered in the sum if they are statistically significant at the 5\% level.

${ }^{20}$ It is common in the related literature to consider a $10 \%$ increase in oil prices, which corresponds in this case with 16 times its standard deviation.
} 
To gain further insights about the inflation gain derived from the change in oil prices, we calculate the steady state gain for each of the five special groups in inflation (see Table 8): processed food (PF), non-energy industrial goods (NEIG), services (SER), non-processed food (NPF) and energy (ENE). The results indicate that an oil price increase only has a relevant impact on energy inflation, which is around 3.5 percentage points for the euro area and Germany, around 3 percentage points for France and Spain, and 2.4 for Italy. Finally, we also compute the steady state gain from a $10 \%$ oil price increase for each of the 58 components of the five special groups (see Figs. 8 and 9): 10 processed foods (PF), 27 non-energy industrial goods (NEIG), 15 services (SER), 4 for non-processed foods (NPF) and 2 energy goods (ENE).

We analyze the effects of the oil price changes on the two components (liquid fuels, and fuels and lubricants for personal transport equipment) of energy inflation. ${ }^{21}$ Figure 8 shows the accumulated TF one-year gains in energy inflation and its components derived from a $10 \%$ increase in the oil prices. The impact on the liquid fuels inflation ranges from 2 percentage points in Italy to 6 percentage points in Germany, but this component has a small weight in the total inflation basket (with a range from $0.4 \%$ in Spain to $0.9 \%$ in Germany). ${ }^{22}$ The impact on inflation of fuels and lubricants for personal transport equipment is smaller than that in the other energy component, although its weight in total inflation is higher and, consequently, it has a larger effect on the aggregated energy and total inflation. In sum, an increase in oil prices leads to an increase mainly in liquid fuels inflation (component with small weight in total inflation) and to a lesser extent in inflation of fuels and lubricants for personal transport equipment (component with a greater weight in total inflation). The euro area (with 3.6 percentage points) and Germany (with 3.5 percentage points) suffer the greatest impact on energy inflation and Italy (with 2.4 percentage points) the lowest effect. The difference effects across countries may be due to either the competitiveness of the energy sector or the taxation system.

We now analyze the impact of an oil price increase on inflation for the 56 goods and services of PF, NEIG, SER and NPF. We find no effect on the inflation of 13 goods and services for all countries. ${ }^{23}$ Thus, Fig. 9 only shows the results for the remaining 43 goods and services. ${ }^{24}$ We observe that the TF effects are highly heterogeneous and without any clear pattern. For many goods and services, the

\footnotetext{
${ }^{21}$ Liquid fuels refer to domestic heating and lighting oils. Fuels and lubricants for personal transport equipment include diesel, petrol and other fuels for personal transport equipment and lubricants.

${ }^{22}$ Note that the consumption structure of households determines the HICP weights (see Footnote 6).

${ }^{23}$ The goods and services with no effect are the following: (1) bread and cereals, (2) milk, cheese and eggs, (3) mineral waters, soft drinks, fruit and vegetable juices, (4) major and small household appliances, (5) equipment reception, recording and reproduction of sound and pictures, (6) photographic and cinematographic equipment and optical instruments, (7) jewellery, clocks and watches, (8) garments, (9) footwear, (10) tools and equipment for house and garden (11) newspapers and periodicals, (12) miscellaneous printed matter; stationery, drawing material, and (13) other services in respect of personal transport equipment.

${ }^{24}$ Following the referee's suggestion, we have replicated our analysis with data before 2010 and we have found that the main conclusions included in the main text remain unaltered when the sample is shorter although the estimates are slightly different.
} 
Table 6 ADF test statistics for the first differences of log HICP of goods and services

\begin{tabular}{|c|c|c|c|c|c|}
\hline & Euro area & Germany & France & Italy & Spain \\
\hline Bread and cereals & $-4.44 * * *$ & $-4.13 * * *$ & $-4.60 * * *$ & $-4.85 * * *$ & $-6.63 * * *$ \\
\hline Milk, cheese and eggs & $-4.91 * * *$ & $-6.44 * * *$ & $-6.45 * * *$ & $-4.81 * * *$ & $-7.84 * * *$ \\
\hline Oils and fats & $-5.98 * * *$ & $-8.22 * * *$ & $-6.24 * * *$ & $-6.14 * * *$ & $-6.54 * * *$ \\
\hline $\begin{array}{l}\text { Sugar, jam, honey, chocolate and } \\
\text { confectionery }\end{array}$ & $-4.82 * * *$ & $-7.78 * * *$ & $-5.84 * * *$ & $-9.43 * * *$ & $-6.37 * * *$ \\
\hline Food products n.e.c. & -4.6 & $-7.41 * * *$ & $-5.86^{* * *}$ & $-6.97 * * *$ & $0 * * *$ \\
\hline Coffee, tea and cocoa & $-4.34 * * *$ & $-6.81 * * *$ & $-5.73 * * *$ & $-5.19 * * *$ & $-6.01 * * *$ \\
\hline $\begin{array}{l}\text { Mineral waters, soft drinks, fruit } \\
\text { and vegetable juices }\end{array}$ & -4.5 & -6.2 & $-6.57 * * *$ & -7.07 & -9 \\
\hline Spirits & $-7.89 * * *$ & $-6.71 * * *$ & $-7.51 * * *$ & $-9.13 * * *$ & $-6.37 * * *$ \\
\hline Wine & $-4.26 * * *$ & $-9.09 * * *$ & $-5.71 * * *$ & $-8.04 * * *$ & $-5.03 * * *$ \\
\hline Beer & $-9.50 * * *$ & $-11.62 * * *$ & $-8.77 * * *$ & $-9.07 * * *$ & $-8.75^{* * *}$ \\
\hline Furniture and furnishings & $-7.06^{* * *}$ & $-11.10 * * *$ & $-15.68 * * *$ & $-10.41 * * *$ & $-7.04 * * *$ \\
\hline Carpets and other floor coverings & $-13.39 * * *$ & $-15.31 * * *$ & $-13.87 * * *$ & $-15.00^{* * * *}$ & $-9.56^{* * *}$ \\
\hline Major, small household appliances & $-5.46^{* * *}$ & $-9.29 * * *$ & $-9.09 * * *$ & $-12.16^{* * *}$ & $-7.49 * * *$ \\
\hline Motor cars & $-9.32 * * *$ & $-9.56 * * *$ & $-14.98 * * *$ & $-12.49 * * *$ & $-10.83 * * *$ \\
\hline $\begin{array}{l}\text { Motor cycles, bicycles and animal } \\
\text { drawn vehicles }\end{array}$ & -8.8 & $-9.50 * * *$ & $-9.79 * * *$ & $-11.05^{* * *}$ & $-12.24 * * *$ \\
\hline $\begin{array}{l}\text { Equip. reception, recording and rep. } \\
\text { sound and pictures }\end{array}$ & $-2.95^{* *}$ & $-5.73 * * *$ & $-5.27 * * *$ & -6 & -4 \\
\hline $\begin{array}{l}\text { Phot. and cinematographic } \\
\text { equipment and optical inst. }\end{array}$ & $-4.17 * * *$ & $-7.34 * * *$ & $-5.84 * * *$ & $-11.09 * * *$ & -3 \\
\hline Information processing equipment & $-6.49 * * *$ & $-6.13 * * *$ & $-9.20 * * *$ & $-10.57 * * *$ & $-7.07 * * *$ \\
\hline Jewellery, clocks and watches & $-3.93 * * *$ & $-12.15 * * *$ & $-5.02 * * *$ & $-6.24 * * *$ & $-4.20 * * *$ \\
\hline Garments & $-15.46^{* * * *}$ & $-12.80 * * *$ & $-17.89 * * *$ & $-16.02 * * *$ & $-13.40 * * *$ \\
\hline $\begin{array}{l}\text { Other articles of clothing and } \\
\text { clothing accessories }\end{array}$ & $-17.35 * * *$ & $-13.93 * * *$ & $-18.55^{* * *}$ & $-14.05^{* * *}$ & $-10.30 * * *$ \\
\hline ar including repair & $-14.32 * * *$ & $-12.88 * * *$ & $-18.97 * * *$ & $-16.52 * * *$ & $-16.33^{* * *}$ \\
\hline Household textiles & $-9.78 * * *$ & $-11.30 * * *$ & $-12.45^{* * *}$ & $-13.88^{* * * *}$ & $-8.92 * * *$ \\
\hline $\begin{array}{l}\text { Glassware, tableware and } \\
\text { household utensils }\end{array}$ & $-8.23 * * *$ & $-10.56^{* * *}$ & $-8.71 * * *$ & $-9.89 * * *$ & $-9.06 * * *$ \\
\hline $\begin{array}{l}\text { Tools and equipment for house and } \\
\text { garden }\end{array}$ & $-8.16^{* * *}$ & $-9.43 * * *$ & $-12.16^{* * *}$ & $-6.41 * * *$ & $-8.36^{* * *}$ \\
\hline $\begin{array}{l}\text { Spares parts, accessories for } \\
\text { personal transport equip. }\end{array}$ & $-6.71 * * *$ & $-10.38 * * *$ & $-4.55^{* * *}$ & $-9.13 * * *$ & $-7.75^{* * *}$ \\
\hline Recording media & $-12.65 * * *$ & $-16.22 * * *$ & $-10.10^{* * * *}$ & $-14.14 * * *$ & $-7.42 * * *$ \\
\hline Games, toys & $-12.41 * * *$ & $-12.51 * * *$ & $-11.45^{* * *}$ & $-13.28 * * *$ & $-9.27 * * *$ \\
\hline $\begin{array}{l}\text { Equipment for sport, camping and } \\
\text { open-air recreation }\end{array}$ & $-11.08 * * *$ & $-9.82 * * *$ & $-12.89 * * *$ & $-13.60 * * *$ & $-8.36^{* * *}$ \\
\hline Other personal effects & $-11.99 * * *$ & $-11.47 * * *$ & $-15.37 * * *$ & $-15.17 * * *$ & $-10.97 * * *$ \\
\hline $\begin{array}{l}\text { Materials for the maintenance and } \\
\text { repair of the dwelling }\end{array}$ & $-10.00 * * *$ & $-10.67 * * *$ & $-12.30 * * *$ & $-9.06^{* * *}$ & $-4.52 * * *$ \\
\hline Non-durable household goods & $-5.40 * * *$ & $-7.45^{* * *}$ & $-6.01 * * *$ & $-6.91 * * *$ & $-9.56^{* * *}$ \\
\hline Gardens, plants and flowers & $-13.28 * * *$ & $-12.10 * * *$ & $-15.18 * * *$ & $-10.12 * * *$ & $-13.05 * * *$ \\
\hline
\end{tabular}


Table 6 continued

\begin{tabular}{|c|c|c|c|c|c|}
\hline & Euro area & Germany & France & Italy & Spain \\
\hline $\begin{array}{l}\text { Pets and related products; } \\
\text { veterinary and other services }\end{array}$ & -7.04 & -012 & $-9.88 * * *$ & $-8.91 * * *$ & $-6.14 * * *$ \\
\hline Newspapers and periodicals & $-10.52 * * *$ & $-10.80 * * *$ & $-15.47 * * *$ & $-13.78 * * *$ & $-9.74 * * *$ \\
\hline $\begin{array}{l}\text { Miscellaneous printed matter; } \\
\text { stationery, drawing mat. }\end{array}$ & $-5.58 * * *$ & $-8.33 * * *$ & $-8.61 * * *$ & $-5.10 * * *$ & $-8.11 * * *$ \\
\hline $\begin{array}{l}\text { Electrical appliances, articles and } \\
\text { products personal care }\end{array}$ & -4.4 & $-8.57 * * *$ & -6. & -8 & $-7.49 * * *$ \\
\hline Actual rentals for housing & $-6.19 * * *$ & $-9.15 * * *$ & $-7.65 * * *$ & $-4.22 * * *$ & $-9.03 * * *$ \\
\hline $\begin{array}{l}\text { Services for the } n \\
\text { repair of the dw }\end{array}$ & $-7.64 * * *$ & $-9.87 * * *$ & $-8.74 * * *$ & $-11.24 * * *$ & $-4.62 * * *$ \\
\hline Repair of household appliances & $-11.16 * * *$ & $-10.15 * * *$ & $-11.45^{* * *}$ & $-11.43^{* * *}$ & $-8.15^{* * *}$ \\
\hline $\begin{array}{l}\text { Domestic services and household } \\
\text { services }\end{array}$ & $-9.81 * * *$ & $-10.00 * * *$ & $-11.19 * * *$ & $-10.49 * * *$ & -4 \\
\hline Recreational and sporting services & $-10.27 * * *$ & $-12.25^{* * *}$ & $-14.46^{* * *}$ & $-12.06^{* * *}$ & $-11.48 * * *$ \\
\hline Restaurants, cafes and the like & $-3.78 * * *$ & $-8.85 * * *$ & $-7.40 * * *$ & $-6.53 * * *$ & $-2.89 * *$ \\
\hline Canteens & $-10.22 * * *$ & $-11.68 * * *$ & $-9.17 * * *$ & $-10.47 * * *$ & $-6.86^{* * *}$ \\
\hline $\begin{array}{l}\text { Hairdressing salons } \\
\text { grooming establis }\end{array}$ & $-8.24 * * *$ & $-8.81 * * *$ & $-7.49 * * *$ & $-8.89 * * *$ & $-8.39 * * *$ \\
\hline Package holidays & $-16.87 * * *$ & $-14.88 * * *$ & $-19.61 * * *$ & $-13.69^{* * *}$ & $59 * * *$ \\
\hline Accommodation services & $-12.72 * * *$ & $-13.71 * * *$ & $-15.48 * * *$ & $-11.59 * * *$ & $-13.72 * * *$ \\
\hline $\begin{array}{l}\text { Maintenance and repair of personal } \\
\text { transport equip. }\end{array}$ & $-5.71 * * *$ & $-9.10^{* * *}$ & $-6.40 * * *$ & $-8.10^{* * *}$ & $-5.92 * * *$ \\
\hline $\begin{array}{l}\text { Other services in respect of } \\
\text { personal transport equip. }\end{array}$ & $-10.67 * * *$ & $-11.54 * * *$ & $-14.54 * * *$ & $-10.19 * * *$ & $-7.34 * * *$ \\
\hline isport by air & $-12.41 * * *$ & $-12.17 * * *$ & $-13.16^{* * *}$ & $-12.27 * * *$ & $-11.27 * * *$ \\
\hline Insurance connected with transport & $-8.90 * * *$ & $-10.22 * * *$ & $-12.73 * * *$ & $-9.19 * * *$ & $-8.63 * * *$ \\
\hline Financial services n.e.c. & $-9.74 * * *$ & $-9.04 * * *$ & $-10.98 * * *$ & $-10.68 * * *$ & $-8.83 * * *$ \\
\hline Meat & $-5.21 * * *$ & $-5.76 * * *$ & $-5.05 * * *$ & $-6.97 * * *$ & $-8.40 * * *$ \\
\hline Fish and seafood & $-10.87 * * *$ & $-10.79 * * *$ & $-14.98 * * *$ & $-10.24 * * *$ & $-12.83 * * *$ \\
\hline Fruit & $-8.89 * * *$ & $-12.00 * * *$ & $-10.87 * * *$ & $-10.22 * * *$ & $-10.40 * * *$ \\
\hline Vegetables & $-11.67 * * *$ & $-12.18 * * *$ & $-13.85^{* * *}$ & $-10.45^{* * *}$ & $-9.68 * * *$ \\
\hline Liquid fuels & $-8.53 * * *$ & $-9.38 * * *$ & $-8.75 * * *$ & $-7.31 * * *$ & $-9.02 * * *$ \\
\hline $\begin{array}{l}\text { Fuels and lubricants for personal } \\
\text { transport equipment }\end{array}$ & $-9.03 * * *$ & $-9.63 * * *$ & $-8.38 * * *$ & $-8.73 * * *$ & $-8.53 * * *$ \\
\hline
\end{tabular}

Ho: Unit root exists. One/two/three asterisks denote significance at the $10 \%, 5 \%$ and $1 \%$ levels, respectively. All test results are based on $p=12$ lags.

effects only occur for one economy. Indeed, we do not find any good or service with effects in the five economies. The largest number of effects occurs in insurance connected with transport (negative for the euro area and positive for Germany, Italy and Spain) and vegetables (positive for Spain and Germany, and negative for France and the euro area). In other cases, like passenger transport by air, the effects on inflation are (as expected) positive for Germany, Italy and the euro area, although there is no effect for Spain and France. One possible explanation for such 
Table $7 p$-values for linear G-Causality test for 58 HICP of goods and services

\begin{tabular}{|c|c|c|c|c|c|}
\hline & $\begin{array}{l}\text { Euro } \\
\text { area }\end{array}$ & Germany & France & Italy & Spain \\
\hline Bread and cereals & 0.27 & 0.16 & 0.18 & 0.18 & 0.14 \\
\hline Milk, cheese and eggs & $0.00 * * *$ & $0.02 * *$ & $0.01 * *$ & 0.31 & $0.06^{*}$ \\
\hline Oils and fats & 0.78 & 0.75 & $0.03 * *$ & 0.73 & 0.36 \\
\hline Sugar, jam, honey, chocolate and confectionery & 0.50 & 0.13 & 0.25 & 0.15 & 0.42 \\
\hline Food products n.e.c. & $0.03 * *$ & 0.63 & 0.18 & 0.29 & 0.51 \\
\hline Coffee, tea and cocoa & 0.83 & 0.84 & 0.54 & 0.79 & 0.64 \\
\hline $\begin{array}{l}\text { Mineral waters, soft drinks, fruit and } \\
\text { vegetable juices }\end{array}$ & 0.28 & 0.39 & 0.68 & 0.30 & 0.92 \\
\hline Spirits & 0.18 & 0.53 & 0.71 & $0.04 * *$ & 0.40 \\
\hline Wine & 0.85 & 0.52 & 0.34 & 0.47 & 0.23 \\
\hline Beer & $0.09 *$ & 0.42 & 0.84 & 0.32 & 0.36 \\
\hline Furniture and furnishings & 0.98 & 0.52 & 0.91 & 0.99 & 1.00 \\
\hline Carpets and other floor coverings & 0.89 & 0.79 & 0.24 & 0.35 & 0.68 \\
\hline Major, small household appliances & 0.64 & 0.30 & 0.84 & 0.80 & 0.97 \\
\hline Motor cars & 0.13 & 0.43 & 0.44 & $0.03 * *$ & 0.66 \\
\hline Motor cycles, bicycles and animal drawn vehicles & 0.41 & 0.81 & 0.41 & 0.70 & 0.23 \\
\hline $\begin{array}{l}\text { Equip. reception, recording and rep. sound and } \\
\text { pictures }\end{array}$ & 0.43 & 0.34 & 0.50 & 0.72 & 0.99 \\
\hline $\begin{array}{l}\text { Phot. and cinematographic equipment and optical } \\
\text { inst. }\end{array}$ & 1.00 & 0.72 & 0.99 & 0.98 & 0.87 \\
\hline Information processing equipment & $0.02 * *$ & 0.35 & $0.05^{*}$ & 0.82 & 0.47 \\
\hline Jewellery, clocks and watches & 0.70 & 0.98 & 0.74 & 0.50 & 0.72 \\
\hline Garments & 0.86 & 0.95 & 0.85 & 0.93 & 0.64 \\
\hline Other articles of clothing and clothing accessories & 0.81 & 0.84 & 0.89 & 0.82 & 0.76 \\
\hline Footwear including repair & 0.85 & 0.98 & 0.92 & 0.76 & 0.81 \\
\hline Household textiles & 0.79 & 0.33 & 0.99 & 0.99 & 0.22 \\
\hline Glassware, tableware and household utensils & 0.97 & 0.23 & 0.43 & 0.79 & 0.92 \\
\hline Tools and equipment for house and garden & 0.82 & 0.94 & 0.93 & 0.84 & 0.49 \\
\hline $\begin{array}{l}\text { Spares parts, accessories for personal transport } \\
\text { equip. }\end{array}$ & 0.89 & 0.96 & 0.99 & 0.55 & 0.72 \\
\hline Recording media & 0.92 & 0.96 & 0.30 & 1.00 & 0.73 \\
\hline Games, toys and hobbies & 0.80 & 0.53 & 0.65 & 0.95 & 0.72 \\
\hline $\begin{array}{l}\text { Equipment for sport, camping and open-air } \\
\text { recreation }\end{array}$ & 0.84 & 0.45 & 0.69 & 0.74 & 0.93 \\
\hline Other personal effects & 0.86 & 0.47 & 0.95 & 0.90 & 0.40 \\
\hline $\begin{array}{l}\text { Materials for the maintenance and repair of the } \\
\text { dwelling }\end{array}$ & 0.59 & 0.30 & 0.73 & 0.71 & 1.00 \\
\hline Non-durable household goods & 0.52 & 0.23 & 0.83 & 0.83 & 0.48 \\
\hline Gardens, plants and flowers & 0.86 & 0.95 & 0.71 & 0.93 & 0.81 \\
\hline $\begin{array}{l}\text { Pets and related products; veterinary and other } \\
\text { services }\end{array}$ & $0.04 * *$ & $0.00^{* * *}$ & 0.29 & 0.91 & $0.02 * *$ \\
\hline Newspapers and periodicals & 0.68 & $0.09 *$ & 0.98 & 0.92 & 0.63 \\
\hline
\end{tabular}


Table 7 continued

\begin{tabular}{|c|c|c|c|c|c|}
\hline & $\begin{array}{l}\text { Euro } \\
\text { area }\end{array}$ & Germany & France & Italy & Spain \\
\hline $\begin{array}{l}\text { Miscellaneous printed matter; stationery, drawing } \\
\text { mat. }\end{array}$ & 0.73 & 0.59 & 0.52 & 0.98 & $0.01 * * *$ \\
\hline $\begin{array}{l}\text { Electrical appliances, articles and products } \\
\text { personal care }\end{array}$ & 0.47 & 1.00 & 0.23 & 0.85 & 0.58 \\
\hline Actual rentals for housing & 0.96 & 0.43 & $0.01 * *$ & $0.09 *$ & 0.90 \\
\hline $\begin{array}{l}\text { Services for the maintenance and repair of the } \\
\text { dwelling }\end{array}$ & 0.67 & 0.97 & $0.06^{*}$ & 0.10 & 0.65 \\
\hline Repair of household appliances & 0.52 & 0.14 & $0.08 *$ & 0.17 & 0.45 \\
\hline Domestic services and household services & $0.09 *$ & 0.96 & 0.76 & $0.07 *$ & 0.47 \\
\hline Recreational and sporting services & 0.14 & $0.03 * *$ & $0.04 * *$ & 0.57 & 0.51 \\
\hline Restaurants, cafes and the like & 0.26 & 0.38 & 0.91 & 0.69 & 0.61 \\
\hline Canteens & 0.38 & 0.53 & 0.32 & 0.50 & 0.33 \\
\hline $\begin{array}{l}\text { Hairdressing salons, personal grooming } \\
\text { establishments }\end{array}$ & 0.80 & 0.74 & 0.85 & 0.44 & 1.00 \\
\hline Package holidays & 0.55 & $0.03 * *$ & 0.73 & 0.46 & 0.36 \\
\hline Accommodation services & 0.99 & 0.89 & 1.00 & 0.98 & 0.74 \\
\hline $\begin{array}{l}\text { Maintenance and repair of personal transport } \\
\text { equip. }\end{array}$ & 0.88 & 0.89 & 0.23 & 0.98 & 1.00 \\
\hline $\begin{array}{l}\text { Other services in respect of personal transport } \\
\text { equip. }\end{array}$ & 0.52 & 0.91 & 0.21 & 0.95 & 0.33 \\
\hline Passenger transport by air & 0.15 & 0.73 & 0.11 & 0.45 & 0.22 \\
\hline Insurance connected with transport & 0.26 & 0.30 & 0.70 & 0.38 & 0.27 \\
\hline Financial services n.e.c. & 0.14 & 0.52 & 0.71 & 0.82 & 0.64 \\
\hline Meat & 0.44 & 0.18 & 0.10 & 0.30 & 0.15 \\
\hline Fish and seafood & $0.07 *$ & 0.36 & $0.01 * *$ & $0.06^{*}$ & 0.23 \\
\hline Fruit & 0.57 & 0.98 & $0.07 *$ & 0.93 & 0.99 \\
\hline Vegetables & 0.10 & $0.04 * *$ & $0.06^{*}$ & 0.78 & 0.30 \\
\hline Liquid fuels & $0.00 * * *$ & $0.00 * * *$ & $0.00 * * *$ & 0.17 & 0.25 \\
\hline $\begin{array}{l}\text { Fuels and lubricants for personal transport } \\
\text { equipment }\end{array}$ & $0.00 * * *$ & $0.02 * *$ & $0.09 *$ & $0.05^{*}$ & 0.10 \\
\hline
\end{tabular}

$H o: P_{t}^{i, j}$ does not G-cause $O_{t}$. One/two/three asterisks denote significance at the $10 \%, 5 \%$ and $1 \%$ levels, respectively. All test results are based on $p=12$ lags.

heterogeneous effects could arise from the differences in the price adjustments among sectors (see Gopinath and Itskhoki 2010). Thus, the low pass-through shown in most of the goods and services in Fig. 9 could be explained by the fact that firms of these sectors adjust prices less frequently.

In short, the positive gain in inflation due to oil price increases for some goods and services may be partially explained by the reduction in the supply, while the negative gain may be associated with the slowdown in the demand. The final sign of the gain depends on the balance between the particular structure in the production and the idiosyncratic factor of consumption and, consequently, we can find opposite 
Table 8 TF gains in percentage points derived from a $10 \%$ oil price increase for total, processed food (PF), non-energy industrial good (NEIG), services (SER), non-processed food (NPF), and energy (ENE) inflation

\begin{tabular}{lllrrrr}
\hline & Total & PF & NEIG & \multicolumn{1}{c}{ SER } & NPF & ENE \\
\hline Euro area & 0.16 & 0.00 & 0.00 & -0.01 & -0.05 & 3.56 \\
Germany & 0.17 & 0.00 & -0.00 & -0.03 & 0.05 & 3.45 \\
France & 0.18 & 0.00 & 0.00 & 0.00 & 0.18 & 3.18 \\
Italy & 0.00 & 0.00 & 0.02 & 0.00 & 0.00 & 2.38 \\
Spain & 0.16 & 0.00 & 0.00 & 0.00 & 0.00 & 2.99 \\
\hline
\end{tabular}

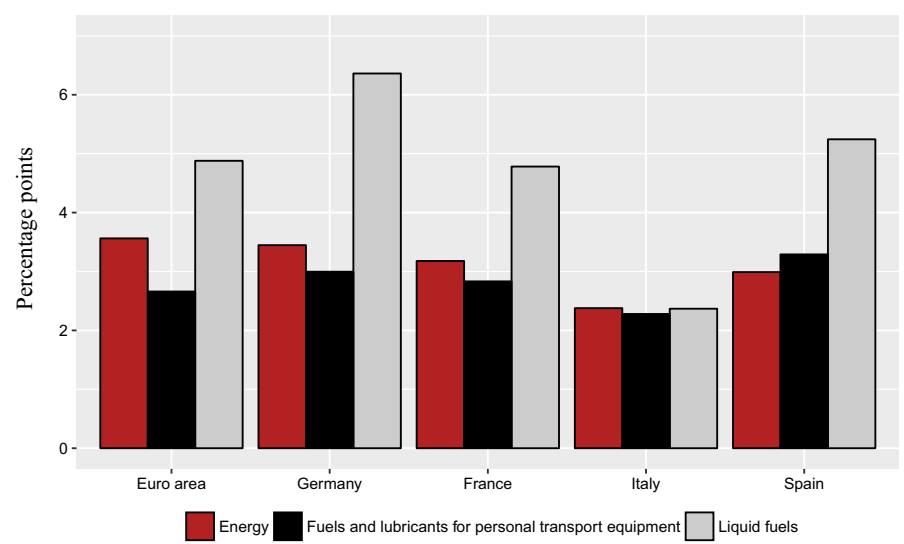

Fig. 8 Effects from a $10 \%$ oil price increase on energy inflation and its components in percentage points

signs for the same good or service in two different economies. This finding might indicate a further loss of competitiveness due to indirect or second-round effects of oil price increases.

Figure 10 plots the number of goods and services with positive, negative and zero gains 12 months after a $10 \%$ oil price shock. We first observe that inflation corresponding to most goods and services remain unchanged when oil price changes. Second, Spain is the economy where oil price changes are disseminated through the inflation of largest number of goods and services (20), while Italy has the lowest number (12). Finally, Germany shows the highest number of goods and services with negative gains (10), likely due to a lower demand, while the largest number of positive effects is found in Spain (14), likely due to a reduction in the supply.

The results shown in Fig. 9 can also be seen as changes in competitiveness of goods and services among economies. When an increase in oil price leads to a rise in inflation for a good/service of one specific economy and a fall in the corresponding inflation for other economy, this may mean a competitiveness improvement for the latter economy. This is, for example, the case of the inflation in 


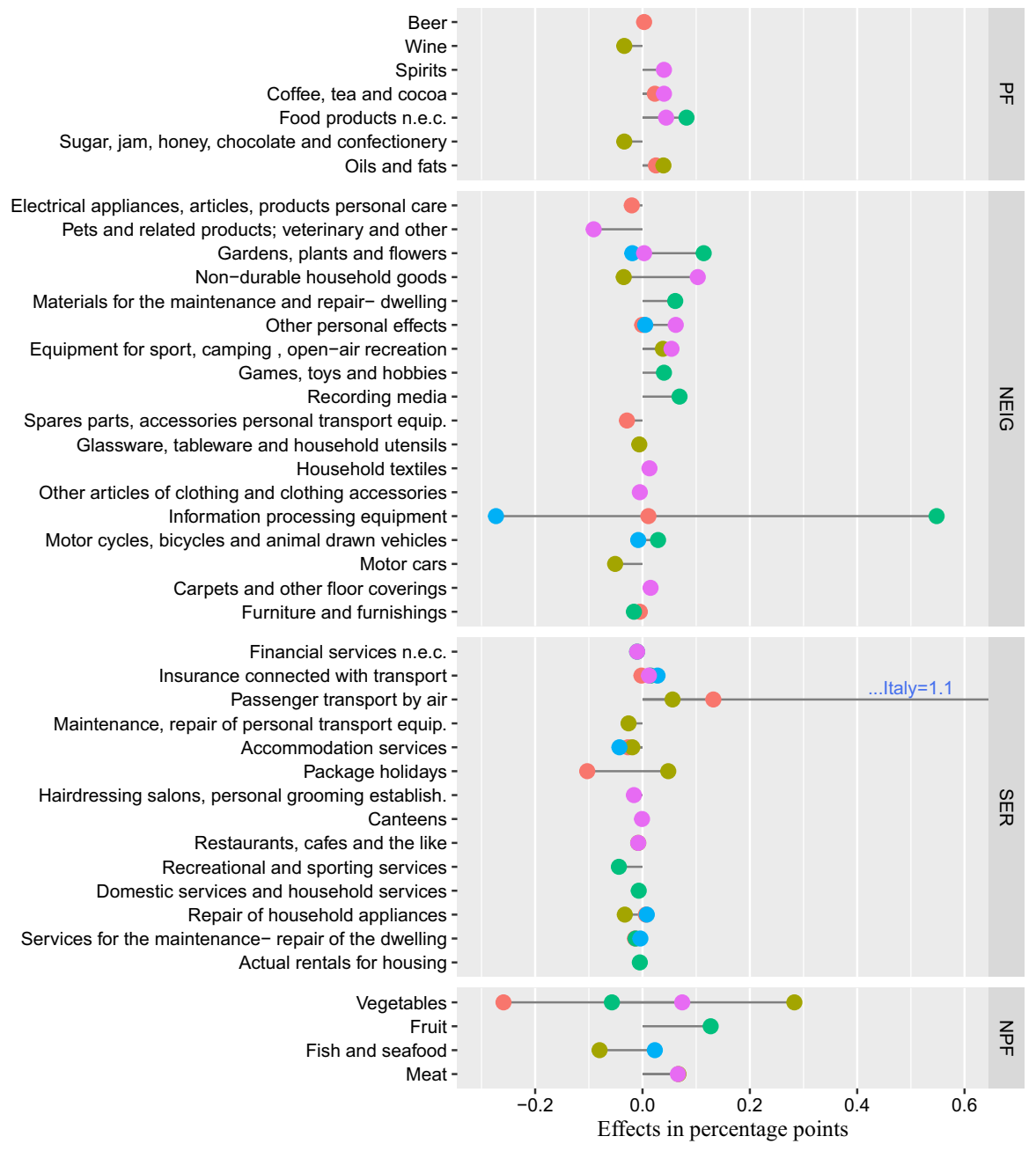

Note: This figure presents the effects (within a year) of a $10 \%$ increase in oil prices on inflation of processed foods (PF), non-energy industrial goods (NEIG), services (SER) and non-processed foods (NPF). When no effect is found for a specific good/service, no sign appears in the Figure.

$$
\text { Euro area Germany } \bigcirc \text { France } \bigcirc \text { Italy Spain }
$$

Fig. 9 Effects in percentage points on inflation of processed foods (PF), non-energy industrial goods (NEIG), services (SER) and non-processed foods (NPF) derived from a growth of $10 \%$ in oil prices within a year, 1996:1-2014:12

nondurable household goods, whose inflation increases in Spain and decreases in Germany due to a positive oil price shock. This can be interpreted as a loss of Spanish competitiveness and a gain of the German one.

An important concern is to analyze the reason why the effects on total inflation are very similar across most countries (Table 8, first column) despite the fact that there are different impacts at disaggregate level (Figs. 9, 8). A possible explanation 


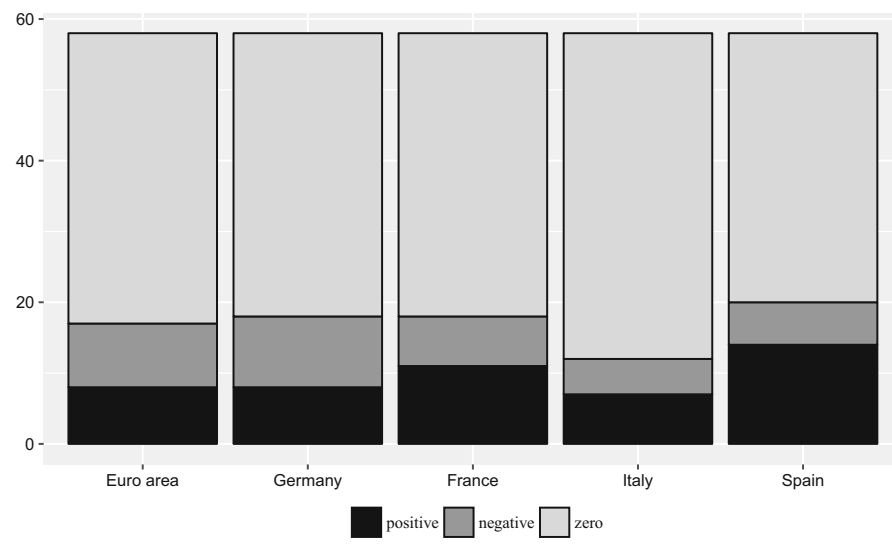

Fig. 10 Number of goods and services according to the positive, negative or zero effects within a year, as a consequence of an increase of 10\% in oil prices, 1996:1-2014:12

Table 9 Indirect calculations of TF gains in percentage points derived from a $10 \%$ oil price increase for total, processed food (PF), non-energy industrial good (NEIG), services (SER), non-processed food $(\mathrm{NPF})$, and energy (ENE) inflation

\begin{tabular}{lccrrrr}
\hline & Total & PF & NEIG & SER & NPF & ENE \\
\hline Euro area & 0.19 & 0.06 & -0.00 & -0.04 & -0.05 & 3.01 \\
Germany & 0.26 & 0.04 & -0.01 & 0.03 & 0.09 & 3.65 \\
France & 0.24 & 0.05 & 0.01 & 0.06 & 0.01 & 3.13 \\
Italy & 0.13 & 0.08 & -0.00 & 0.02 & 0.00 & 2.29 \\
Spain & 0.27 & 0.09 & 0.01 & 0.02 & 0.04 & 3.44 \\
\hline
\end{tabular}

could be that positive and negative indirect and second-round effects (those affecting especially non-energy goods and services) offset the positive effects found on energy inflation, dissipating the effects on total inflation. In this sense, Fig. 8 suggests that the calculation of effects in the aggregate variables (i.e., total inflation) could hide a wide range of effects on their disaggregated components, to the extent that we could not find any effect on aggregate variables. That is the case of Italy, where an important effect on energy inflation is found and no effect appears in the direct TF gain of total inflation (see Table 8). Thus, an alternative approach is to calculate indirectly the effects on total inflation (or the groups of inflation) aggregating the impact on its components with their corresponding weights. ${ }^{25}$ The results are shown in Table 9. In the case of energy inflation, the aggregate effects are similar to the direct calculation shown in Table 8. In other groups, the results using

\footnotetext{
25 This approach allows to use a more flexible modeling for the idiosyncratic properties of the inflation components. Also, it allows to measure individual pass-through patterns for different inflation components and thus to analyze the good/service price that is more directly related to oil prices (see, e.g., Theil 1954; Benalal et al. 2004; Hubrich 2005). Notwithstanding this, it is worth noting that the aggregate approach also shows some potential advantages since the noise in the disaggregate level may average out in the aggregate.
} 
the indirect method are similar to those considering the direct one, with the exception of the effects on inflation of processed food (PF). Furthermore, the effect on total inflation obtained by the indirect method is higher than that found using the direct method in all economies. In particular, the impact on total inflation by aggregation of effects (indirect method) is 0.13 percentage points in Italy.

\section{Conclusions}

This paper provides an exhaustive examination of the effects of oil price changes in inflation for the euro area and its main economies (France, Germany, Italy and Spain) by using a disaggregated approach.

In a first disaggregation of inflation in energy and non-energy components, we find that changes in oil price have a large and clear direct impact on energy inflation, although the effect on total inflation seems to be weak. There is a strong contribution of energy inflation due to an oil price increase to total inflation in Germany, but the reaction of non-energy inflation helps to contain considerably total inflation. However, both energy and non-energy inflation contribute notably to total inflation in Spain. These differences across countries might be explained by the indirect or second-round effects, the differences in consumption and production structures, and the specific taxation and regulation of each domestic market.

To better understand the oil price pass-through into inflation, we consider a deeper disaggregation of inflation (excluding goods and services with administered prices to avoid the distortionary influence of price movements outside of the market forces). On looking at the disaggregation of inflation for the special group "energy", we observe that the largest effect to an oil price increase corresponds to the inflation of fuels and lubricants for personal transport equipment in Spain, which is consistent with (a) its more direct transmission due to lower taxes, (b) its larger dependence on energy, and (c) its largest consumer's spend in this product.

Regarding the other special groups (processed and non-processed food, nonenergy industrial goods and services), we observe a small significant gain in the corresponding special group inflation after an oil price increase. Looking at the disaggregate level, we obtain that the prices of the goods and services considered remain unchanged after an oil price shock, which is consistent with a low price elasticity of demand for energy, typical of advanced economies, which causes marginal variations in the demand for non-energy goods and services. Moreover, when a reaction is obtained we observe different responses across countries and across items, which may be associated with indirect and second-round effects. These differences are partly the consequence of specific domestic structure in the production and the idiosyncratic factor of consumption.

We found that Spain shows the largest number of goods and services with positive effects on inflation derived from oil price changes, maybe due to a slowdown in domestic supply. This means a loss of competitiveness for these goods and services in Spain. By contrast, Germany shows the largest number of negative effects on inflation, maybe due to a slowdown in domestic demand, which means a competitiveness gain. 
Finally, our findings suggest that aggregation of effects at disaggregate level is an alternative method to their direct calculation given that indirect and second-round effects (those affecting especially non-energy goods and services) may offset the positive effects found in energy inflation and dissipate the effect on total inflation.

Open Access This article is distributed under the terms of the Creative Commons Attribution 4.0 International License (http://creativecommons.org/licenses/by/4.0/), which permits unrestricted use, distribution, and reproduction in any medium, provided you give appropriate credit to the original author(s) and the source, provide a link to the Creative Commons license, and indicate if changes were made.

\section{References}

Altissimo, F., Mojon, B., \& Zaffaroni, P. (2009). Can aggregation explain the persistence of inflation? Journal of Monetary Economics, 56(2), 231-241.

Álvarez, L., Hurtado, S., Sánchez, I., \& Thomas, C. (2011). The impact of oil price changes on Spanish and euro area consumer price inflation. Economic Modelling, 28, 422-431.

Bachmeier, L., \& Cha, I. (2011). Why don't oil price shocks cause inflation? Evidence from disaggregate inflation data. Journal of Money, Credit and Banking, 43(6), 1165-1183.

Barsky, R., \& Kilian, L. (2004). Oil and the macroeconomy since the 1970s. Journal of Economic Perspectives, 18, 115-134.

Baumeister, C., \& Peersman, G. (2013a). The role of time-varying price elasticities in accounting for volatiltity changes in the crude oil market. Journal of Applied econometrics, 28, 1087-1109.

Baumeister, C., \& Peersman, G. (2013b). Time-varying effects of oil supply shocks on the U.S. economy. American Economic Journal: Macroeconomics, 5(4), 1-28.

Bekiros, S., Gupta, R., \& Paccagnini, A. (2015). Oil price forecastability and economic uncertainty. Economics Letters, 132, 125-128.

Bekiros, S., \& Paccagnini, A. (2016). Policy-oriented macroeconomic forecasting with hybrid DSGE and time-varying parameter var models. Journal of Forecasting (forthcoming).

Benalal, N., del Hoyo, J. L. D., Landau, B., Roma, M., \& Skudelny, F. (2004). To aggregate or not to aggregate? Euro area inflation forecasting. Working Paper Series 0374, European Central Bank.

Blanchard, O., \& Galí, J. (2010). The macroeconomic effects of oil shock: Why are the 2000s so different from the 1970s? In: J. Galí, M. Gertler (Eds.) International dimensions of monetary policy (pp. 373-421). University of Chicago Press, Chicago.

Castro, C., Jerez, M., \& Barge-Gil, A. (2016). The deflationary effect of oil prices in the euro area. Energy Economics, 56, 389-397.

Chen, S-S. (2009). Oil price pass-through into inflation. Energy Economics, 31(1), 126-133.

Clark, T. (2006). Disaggregate evidence on the persistence of consumer price inflation. Journal of Applied Econometrics, 587(21), 563-587.

DeGregorio, J., Landerretche, O., Neilson, C., Broda, C., \& Rigobon, R. (2007). Another pass-through bites the dust? Oil prices and inflation. Economia, 7(2), 155-208.

Diks, C., \& Panchenko, V. (2006). A new statistic and practical guidelines for nonparametric granger causality testing. Journal of Economic Dynamics and Control, 30, 1647-1669.

ECB. (2010). Energy markets and the euro area macroeconomy. ECB Occasional Paper. No. 113.

Edelstein, P., \& Kilian, L. (2007). The response of business fixed investment to changes in energy prices: A test of some hypotheses about the transmission of energy price shocks. The B.E. Journal of Macroeconomics, 7(1).

Edelstein, P., \& Kilian, L. (2009). How sensitive are consumer expenditures to retail energy prices? Journal of Monetary Economics, 56(6), 766-779.

Espasa, A., \& Albacete, R. (2007). Econometric modelling for short-term inflation forecasting in the euro area. Journal of Forecasting, 26(5), 303-316.

Espasa, A., \& Mayo-Burgos, I. (2013). Forecasting aggregates and disaggregates with common features. International Journal of Forecasting, 29(4), 718-732. 
Espasa, A., Senra, E., \& Albacete, R. (2002). Forecasting inflation in the european monetary union: A disaggregated approach by countries and by sectors. The European Journal of Finance, 8(4), 402-421.

Gopinath, G., \& Itskhoki, O. (2010). Frequency of price adjustment and pass-through. The Quarterly Journal of Economics, 125(2), 675-727.

Grunfeld, Y., \& Griliches, Z. (1960). Is aggregation necessarily bad? The Review of Economics and Statistics, 42(1), 1-13.

Hamilton, J. (1983). Oil and the macroeconomy since world war II. Journal of Political Economy, 91(2), 228-248.

Hamilton, J. (2009a). Causes and consequences of the oil shock of 2007-08. Brookings Papers on Economic Activity, 1, 215-261.

Hamilton, J. (2009b). Understanding crude oil prices. Energy Journal, 30(2), 179-206.

Hamilton, J., \& Herrera, A. M. (2004). Oil shocks and aggregate macroeconomic behavior: The role of monetary policy. Journal of Money, Credit and Banking, 36(2), 265-286.

Hendry, D. F., \& Hubrich, K. (2011). Combining disaggregate forecasts or combining disaggregate information to forecast an aggregate. Journal of Business \& Economic Statistics, 29(2).

Hubrich, K. (2005). Forecasting euro area inflation: Does aggregating forecasts by hicp component improve forecast accuracy. International Journal of Forecasting, 21(1), 119-136.

Jiménez-Rodríguez, R., \& Sánchez, M. (2005). Oil price shocks and real gdp growth: empirical evidence for some oecd countries. Applied Economics, 37(2), 201-228.

Kilian, L. (2008). The economic effects of energy price shocks. Journal of Economic Literature, 46(4), 871-909.

Kilian, L. (2009). Not all oil price shocks are alike: Disentangling demand and supply shocks in the crude oil market. American Economic Review, 99(3), 1053-1069.

Kilian, L. (2014). Oil price shocks: Causes and consequences. Annual Review of Resource Economics, 6 , $133-154$.

Kilian, L., \& Vega, C. (2011). Do energy prices respond to U.S. macroeconomics news? a test of the hypothesis of predetermined energy prices. The Review of Economics and Statistics, 93(2), 660-671.

Lippi, M., \& Forni, M. (1990). On the dynamic specification of aggregated models. In Hashem Pesaran (Ed.), Terry Barker and M. Cambridge: Disaggregation in Econometric Modelling. Routledge.

Liu, L.-M., \& Hanssens, D. (1982). Identification of multiple-input transfer function models. Communications in Statistics-Theory and Methods, 11(3), 297-314.

Liu, L.-M., Hudak, G., Box, G. E. P., Muller, M., \& Tiao, G. C. (1992). Forecasting and Time Series Analysis Using the SCA Statistical System: Volume 1. Scientific Computing Associates Corp.

Mandal, K., Bhattacharyy, I., \& Bhoi, B. B. (2012). Is the oil price pass-through in india any different? Journal of Policy Modeling, 34(6), 832-848.

Nijman, T., \& Sentana, E. (1996). Marginalization and contemporaneous aggregation in multivariate garch processes. Journal of Econometrics, 71(1-2), 71-87.

Pesaran, M. H., Pierse, R. G., \& Kumar, M. S. (1989). Econometric analysis of aggregation in the context of linear prediction models. Econometrica, 57(4), 861-888.

Riggi, M., \& Venditti, F. (2015). The time varying effect of oil price shocks on euro-area exports. Journal of Economic Dynamics and Control, 59, 75-94.

Segal, P. (2011). Oil price shocks and the macroeconomy. Oxford Review of Economic Policy, 27(1), $169-185$.

Theil, H. (1954) Linear aggregation of economic relations. Contributions to economic analysis. NorthHolland Pub. Co.

Valcarcel, V. J., \& Wohar, M. E. (2013). Changes in the oil price-inflation pass-through. Journal of Economics and Business, 68, 24-42. 